\title{
Fanatic and Energetic Participation in Sports
}

\author{
By Seppo Suominen*
}

Sport participation can be classified into fanatic and energetic. Fanatic is related to attendance at sport events. Energetic sport participation is that a person exercises some sport activity by herself/himself. Using bivariate probit allows us to separate the direct and indirect marginal effects of different explanatory variables. A selection of some socio-economic variables is used here to explain the profile of passive and active sport participation. The data is taken from ISSP 2007 which is a mainly European level survey on these issues. A bivariate probit model explaining sport participation, both fanatic (attending sporting events) and energetic (exercising yourself) sport participation is estimated first. The above mentioned variables - age, the body-mass index, the educational level, gender and marital status and incomes. are used as explanatory variables 34 estimations in each country. Some of the variables are not available for each county, for example the body-mass index is usually not available. The second step is to analyze the marginal effects of gender using Hofstede's cultural dimensions. The second step analysis reveals that individualism, uncertainty avoidance and indulgence are the dimensions that significantly explain gender differences in sporting behavior.

Keywords: Fanatic, Energetic, Sport Participation, ISSP 2007.

\section{Introduction and Motivation}

Sport participation can be classified into fanatic and energetic. Fanatic is related to attendance at sport events: for example a person goes to see an ice hockey game. Energetic sport participation is that a person exercises some sport activity by herself/himself: for example she exercises aesthetic group gymnastics or he plays football. There is a wide literature on the profiles of sport participation. We know already who is active in playing football and we know what the spectator profile is (Downward 2007, Cabane and Lechner 2014, Borland and MacDonald 2003). However, we do not know how these groups are interrelated. This information is important for the purpose of understanding the different or similar motives of attending sport events and exercising sport. It is also possible that we observe differences across countries.

The aim of this study is to do a detailed research into the profiles of fanatic and energetic sport participation using suitable econometric methods. A suitable method here is bivariate probit since it allows us to separate the direct and indirect marginal effects of different explanatory variables. A selection of some socio-economic variables is used here to explain the profile of passive (fanatic) and active (energetic) sport participation.

\footnotetext{
*Senior Lecturer, Haaga-Helia University of Applied Sciences, Finland.
} 
The data is taken from ISSP 2007 which is a mainly European level survey on these issues. The overall size of the sample is about 49,000 individual in 34 different countries varying from East Asia (Japan, Philippines, South Korea and Taiwan) and America (Chile, Dominican Republic, Mexico, USA and Uruguay) to Europe. Australia and South Africa are also included in the sample. In the sample two sport related questions were asked about the frequency of free time activities: "How often do you do each of the following activities in your free time: take part in physical activities such as sports, going to the gym, going for a walk? " and "How often do you do each of the following activities in your free time: attend sporting events as a spectator?". The first question is called in this study energetic and the second fanatic. Five alternatives were given to the respondents: "daily", "several times a week", "several times a month", "several times a year or less often" and "never".

The data has been used by Ruseski and Maresova (2014). They show that a high gross domestic product per capita and economic freedom are positively related with higher physical activity participation (energetic sport participation). It falls with age and rises with higher education and income. They also show that internationally men are more energetic. However, the last observation does not hold in some Scandinavian countries (Hartmann-Tews 2006). This distinction raises the question whether there are significant differences among nations.

A health enhancing physical activity recommendation in Finland (Ukkinstituutti 2015) states that adults should exercise sports "several times a week". If we add the first ("daily") and second ("several times a week") alternatives and call this energetic (exercise often) or fanatical (attend often), the most energetic nations are Western: Switzerland (69\%), Finland (64\%), New Zealand (63\%), Sweden (60\%) and Norway (57\%). The most fanatical nations are Israel (27\%), Philippines (24\%), Dominican Republic (17\%), Mexico (11\%) and South Africa (9\%). The correlation of the energetic and fanatical variables is negative: $-0.287(n=34$, countries $)$. However, the Spearman correlation of individuals' active and passive sport participation $(\mathrm{n}=48.949$, range from "daily" to "never") is positive: 0.268 . This rough analysis reveals that a more detailed study must be drawn up. It is noteworthy to state that the individuals' energetic and fanatic sport participation correlation is the lowest in Cyprus (0.009), Finland (0.060), Switzerland (0.087), Taiwan (0.105) and Sweden (0.115). This correlation coefficient and the energetic variable are negatively correlated $(-0.547, n=34)$ indicating that energetic and fanatic individuals are probably most separated in energetic countries. On the basis of the preliminary analysis, a hypothesis can be drawn: in relatively rich countries the individuals are energetic and in relatively lower level income countries individuals are more fanatical.

However, the hypothesis presented above - in relatively rich countries the individuals are energetic and in relatively lower level income countries individuals are more fanatical - might be biased since the gender differences are substantial. The first step is to analyze energetic and fanatic sport participation. The effects of gender on fanatic and energetic participation in 
sport are estimated using bivariate probit analysis. The second step is to use the bivariate probit results in seemingly unrelated regression (SURE) estimations where the explanatory variables are Hofstede's culture dimensions. The aim of the second step is to show how these dimensions could be used to understand gender differences in sporting behaviour.

\section{Literature Review}

There are substantial differences in participation rates in sport and recreational physical activity in Europe (Hartmann-Tews 2006). In some countries, the participation rate is about one third of the population (Portugal, Hungary), while in the Nordic countries the rate is more than $90 \%$ (van Tuyckom 2013). The European Sport Charter first launched in 1975 to encourage active sport participation. Since that time, the Charter has been reformed several times in order to provide a common set of policies for all Europe. According to these policies, sport must be accessible to everybody, available for children and young people in particular, healthy and safe, fair and tolerant, building on high ethical values, capable of fostering personal selffulfillment at all levels, respectful of the environment, protective human dignity and against any kind of exploitation of those engaged in sport (The Council of Europe 2014). Empirical research has shown that within EU substantial differences still exist. Hartmann-Tews (2006) also shows that age, the educational level and gender are important determinants of the energetic participation in sports. In the EU, only six countries have a gender-neutral inclusion profile: Finland, Sweden, Denmark, the Netherlands, Estonia and Malta. Otherwise men and boys are more active. With respect to age the energetic participation seems to decrease. In EU 25, more than $80 \%$ of the youngest cohort (15-24 years old) participate, while only one third of the oldest cohort (more than 65) are physically active. The results also indicate that activity is directly linked to the level of education, those with lower education are less active than those with higher education. Recently, van Tuyckom (2013) classified EU 25 countries using cluster analysis based on Eurobarometer 2004 survey. The hierarchical cluster analysis dendrogram shows that the pairings of Finland, Sweden, Portugal, Italy and Greece are very distant from the others. Van Tuyckom (2013) classifies the countries into six clusters and uses the following typology: 1) non to average fitness sporting countries (Greece, Italy and Portugal), 2) active club sporting countries (Denmark, Netherlands and Austria), 3) average non-organized sporting countries (Slovenia, Malta, and Cyprus), 4) average school sporting countries (Hungary, Latvia Lithuania and Poland), 5) active multi-context sporting countries (Belgium, Germany, Spain, France, Ireland, Luxembourg, UK, Czech and Slovakia) and 6) very active sporting countries (Finland and Sweden). There is a very large cultural diversity; each country has its own tradition.

Using the Scottish Health Survey 2003 Eberth and Smith (2010) find that sports participation and duration significantly reduce with the increasing age and men are more likely to participate sports relative to women. The effect of 
infants and marital status is significant only for women. Low income is an important barrier to participate. More educated have a higher propensity to participate in sports. Eberth and Smith (2010) classify the duration of sport activity into low, moderate or high vigor participation. Only vigor participation has a significant declining effect on the body-mass index (BMI) emphasizing the health benefits due to participation. Wicker et al. (2013) recently showed that the sport infrastructure has an important and significant impact on sport participation. After controlling the conventional variables ${ }^{1}$, like time restrictions due to relatives and children, participant's age and education, the infrastructure measured by the provision of sport fields, swimming pools or gymnastic/dancing rooms and park area are important determinants of sport participation in München, Germany. Wicker et al. (2013) also show that migration background has an impact. The importance of the ethnic background has been found also by Humphreys and Ruseski (2009).

Hofstede's (1980) country classification into eight cultural clusters has been used by Funk et al. (2007) to explain prior sport motives, destination image and travel motives in an Australian running event (Hallmark marathon). More developed Latin, less developed Latin, more developed Asian, less developed Asian, near Eastern, Germanic, Anglo and Nordic countries is the cultural background of the participant in the running event. The results reveal that the travel motivation differed by gender and cultural background. Even though Hofstede's dimensions have been criticized ${ }^{2}$ Hofstede (2002) argues that culture could be useful to explain behavior since culture has certain values and individuals within that culture share these values.

In the late 1970's a Dutch social psychologist and organizational anthropologist Geert Hofstede created a new paradigm to study cultural differences: a four-dimensional model of national culture. Later that model has been updated on the basis of cross-cultural analysis. The basic problems that all nations have to manage are characterized with four dimensions: power distance (social inequality, relationship with authority), individualism-collectivism, masculinity-femininity and uncertainty avoidance. The fifth dimension was first introduced in 2005 (Hofstede and Hofstede 2005). It was called long-term vs. short-term orientation. The last, sixth dimension was added in 2010 (Hofstede et al. 2010): indulgence vs. restraint.

Hofstede et al. (2010: 61) defines power distance as the extent to which the less powerful members of institutions and organizations within a country expect and accept that power is distributed unequally. Some cultures are characterized by power respect. People tend to accept the power and authority of their superiors on the basis of their positions in the hierarchy and people also respect the superiors' right to that power. Respectively in cultures characterized by power tolerance people attach less significance to a superior's position in the hierarchy. Subordinates are willing to follow a leader when that leader is conceived to be right or when it seems to be in their own self-interest

\footnotetext{
1 e.g. Martinez-Gonzalex et al. (2001), Downward and Riordan (2007), Breuer et al. (2010), Rovio et al. (2011).

${ }^{2}$ Javidan et al. (2006) or Soares et al. (2007).
} 
to do so. In the ISSP 2007 data power respect countries are e.g. Slovakia, Philippines and Russia; while Austria, Israel and Scandinavian countries are power tolerant (Hofstede et al. 2010: 59).

Individualism is attached to societies where the ties between individuals are loose, while collectivism is the opposite; people are integrated into strong, cohesive in-groups (Hofstede et al. 2010: 92). In individualism, the person comes first; they have a high degree of self-respect and independence. In collectivist societies, the group comes first; there is a well-defined social network and the behaviour is such culture is strongly influenced by the emotion of shame. When a group fails, its members take the failure very personally and experience shame. Hofstede (1980) suggests that people in the USA, UK and Australia for instance are individualistic while in Mexico, Taiwan and South Korea collectivism is more common.

Hofstede (2011: 11) lists ten differences between individualist and collectivist societies:

Table 1. Differences between Individualist and Collectivist Societies

\begin{tabular}{|c|c|}
\hline Individualism & Collectivism \\
\hline $\begin{array}{l}\text { Everyone is supposed to take care of him - of } \\
\text { herself and his/her immediate family only }\end{array}$ & $\begin{array}{l}\text { People are born into extended families or } \\
\text { clans which protect them in exchange for } \\
\text { loyalty }\end{array}$ \\
\hline "I" - consciousness & "We" - consciousness \\
\hline Right of privacy & Stress on belonging \\
\hline Speaking one's mind is healthy & Harmony should always be maintained \\
\hline Other classified as individuals & Others classified as in-group or out-group \\
\hline $\begin{array}{l}\text { Personal opinion expected: one person one } \\
\text { vote }\end{array}$ & $\begin{array}{l}\text { Opinions and votes predetermined by in- } \\
\text { group }\end{array}$ \\
\hline Transgression of norms leads to guilt feelings & $\begin{array}{l}\text { Transgression of norms leads to shame } \\
\text { feelings }\end{array}$ \\
\hline $\begin{array}{l}\text { Languages in which the word "I" is } \\
\text { indispensable }\end{array}$ & Languages in which the word "I" is avoided \\
\hline Purpose of education is learning how to learn & Purpose of education is learning how to do \\
\hline Task prevails over relationship & Relationship prevails over task \\
\hline
\end{tabular}

Source: Prepared by Author.

A society is called masculine when emotional gender roles are clearly distinct: men are assumed to be assertive and tough, and they are focusing on material success, while women are presumed to be modest, tender and concerned with the quality of life. In a feminine society the gender roles overlap; both men and women are assumed to be modest, tender and concerned with the quality of life. The most feminine-scoring countries are Scandinavian and the Netherlands in the ISSP 2007 sample, while Anglo countries such as the USA, UK, Australia and South Africa are masculine.

Uncertainty avoidance is the extent to which the members of a culture feel threatened by ambiguous or unknown situations. This phrase should not be confused with risk avoidance. Uncertainty is to risk as anxiety is to fear (Hofstede et al. 2010: 197). Risk is usually expressed as probability while anxiety and uncertainty are diffuse feelings. Uncertainty acceptance is closely related to stimulation by change and thrives on new opportunities, while people 
in cultures characterized by uncertainty avoidance dislike ambiguity. These people prefer routine and structured situations. High scores of uncertainty avoidance occur for Latin American (Chile in the ISSP 2007 sample), Latin European and Mediterranean (France) countries, whereas Anglo (UK and Ireland) and Nordic (Sweden and Norway) are uncertainty tolerant.

Based on Hofstede (2011: 10) there are ten differences between weak and strong uncertainty avoidance societies:

Table 2. Differences between Weak and Strong Uncertainty Avoidance Societies

\begin{tabular}{|l|l|}
\hline \multicolumn{1}{|c|}{ Weak uncertainty avoidance } & \multicolumn{1}{c|}{ Strong uncertainty avoidance } \\
\hline $\begin{array}{l}\text { The uncertainty inherent in life is accepted } \\
\text { and each day is taken as it comes }\end{array}$ & $\begin{array}{l}\text { The uncertainty inherent in life is felt as a } \\
\text { continuous threat that must be fought }\end{array}$ \\
\hline Ease, lower stress, self-control, low anxiety & $\begin{array}{l}\text { Higher stress, emotionality, anxiety, } \\
\text { neuroticism }\end{array}$ \\
\hline $\begin{array}{l}\text { Higher scores on subjective health and well- } \\
\text { being }\end{array}$ & $\begin{array}{l}\text { Lower scores on subjective health and well- } \\
\text { being }\end{array}$ \\
\hline $\begin{array}{l}\text { Tolerance of deviant persons and ideas: what } \\
\text { is different is curious }\end{array}$ & $\begin{array}{l}\text { Intolerance of deviant persons and ideas: what } \\
\text { is different is dangerous }\end{array}$ \\
\hline Comfortable with ambiguity and chaos & Need for clarity and structure \\
\hline Teachers may say "I don't know" & Teachers supposed to have all the answers \\
\hline Changing jobs no problem & Staying in jobs even if disliked \\
\hline Dislike of rules - written or unwritten & Emotional need for rules - even if not obeyed \\
\hline $\begin{array}{l}\text { In politics, citizens feel and are seen as } \\
\text { competent towards authorities }\end{array}$ & $\begin{array}{l}\text { In politics, citizens feel and are seen as } \\
\text { incompetent towards authorities }\end{array}$ \\
\hline $\begin{array}{l}\text { In religion, philosophy and science: relativism } \\
\text { and empiricism }\end{array}$ & $\begin{array}{l}\text { In religion, philosophy and science: belief in } \\
\text { ultimate truths and grand theories }\end{array}$ \\
\hline
\end{tabular}

Source: Prepared by Author.

The original IBM studies made by Hofstede (1980) resulted in four dimensions of national cultures: power distance, individualism-collectivism, masculinity-femininity and uncertainty avoidance). These are dimensions of values (Hofstede et al. 2010: 353). Pragmatism is a dimension in organizational culture. It is associated with customer orientation. Pragmatic units and people are market driven and the opposite, normative units follow inviolable rules and organizational procedures. Pragmatic people emphasize results more than correct procedures. Typically privately owned units are pragmatic, public units are more normative. Pragmatism is often related to long-term orientation and normative to short-term orientation (Hofstede and Murff 2012). The USA, Philippines and Ireland are more normative, whereas Taiwan, Japan and Belgium are more pragmatic countries.

Hofstede (2011) defines indulgence as follows: "Indulgence stands for a tendency to allow the relatively free gratification of basic and natural human desires related to enjoying life and having fun".

The opposite pole, restraint stands for a curbed and regulated gratification by social norms. Indulgence refers to enjoying life and having fun and not to saturate all human desires in general. In the ISSP 2007 sample Mexico, Sweden and New Zealand are relatively indulgent, while Latvia, South Korea and Poland are restraint relative to other sample countries. The importance of 
leisure is different in indulgent and restraint societies: indulgent countries emphasize more leisure than restrained do.

The ten differences between indulgent and restrained societies are (Hofstede 2011: 16):

Table 3. Differences between Indulgent and Restrained Societies

\begin{tabular}{|l|l|}
\hline \multicolumn{1}{|c|}{ Indulgence } & \multicolumn{1}{|c|}{ Restrained } \\
\hline $\begin{array}{l}\text { Higher percentage of people declaring } \\
\text { themselves very happy }\end{array}$ & Fewer very happy people \\
\hline A perception of personal life control & $\begin{array}{l}\text { A perception of helplessness: what happens } \\
\text { to me is not my own doing }\end{array}$ \\
\hline Freedom of speech seen as important & Freedom of speech is not a primary concern \\
\hline Higher importance of leisure & Lower importance of leisure \\
\hline More likely to remember positive emotions & Less likely to remember positive emotions \\
\hline $\begin{array}{l}\text { In countries with educated populations, } \\
\text { higher birth-rates }\end{array}$ & $\begin{array}{l}\text { In countries with educated populations, } \\
\text { lower birth-rates }\end{array}$ \\
\hline More people actively involved in sports & Fewer people actively involved in sports \\
\hline $\begin{array}{l}\text { In countries with enough food, higher } \\
\text { percentages of obese people }\end{array}$ & $\begin{array}{l}\text { In countries with enough food, fewer obese } \\
\text { people }\end{array}$ \\
\hline In wealthy countries, lenient sexual norms & In wealthy countries, stricter sexual norms \\
\hline $\begin{array}{l}\text { Maintaining order in the nation is not given } \\
\text { a high priority }\end{array}$ & $\begin{array}{l}\text { Higher number of police officers per } \\
100.000 \text { population }\end{array}$ \\
\hline
\end{tabular}

Source: Prepared by Author.

\section{A Model and Method}

Following García et al. (2011) consumers' preferences are written in terms of time spent on different sport activities $\left(l_{\mathrm{f}}\right.$ and $\left.\mathrm{l}_{\mathrm{e}}\right)$ and net income $(\mathrm{m})$. The net income can be used to consumption that is not related to leisure. Leisure is used in fanatic sport participation (attending a sport event, $\mathrm{l}_{\mathrm{f}}$ ) and energetic or physical sport participation (exercising physical sport $1_{\mathrm{e}}$ ). The structure of consumer preferences is assumed to be a CES utility function due to its convenient marginal rate of substitution (MRS) features. The consumer's optimization problem is:

$$
\begin{gathered}
\max _{m, l_{f}, l_{e}} U\left(m, l_{f}, l_{e}\right)=\left[m^{-\mu}+\beta l_{f}^{-\mu}+\gamma l_{e}^{-\mu}\right]^{-\frac{1}{\mu}} \text { s.t. } m= \\
w\left(T-l_{f}-l_{e}\right)+y
\end{gathered}
$$

Where $U$ denotes utility, $\mu$ is a parameter closely related to constant elasticity of substitution and it must be greater than $-1, \beta$ and $\gamma$ are positive parameters, $\mathrm{w}$ is hourly earnings, $\mathrm{T}$ is time available (168 hours a week) and finally $\mathrm{y}$ is non-labour income. By solving the optimization problem including the budget constraint, consumer's demands for attending sport event $\left(1_{\mathrm{f}}\right)$ and exercising sport $\left(l_{\mathrm{e}}\right)$ can be obtained. Interior solutions of the optimization problem denote that the MRS between net income $(\mathrm{m})$ and either attending sport event or exercising sport must be equal to the hourly earnings: 


$$
\begin{aligned}
\mathrm{MRS}_{\mathrm{m}, \mathrm{l}_{\mathrm{f}}} & =\frac{\partial \mathrm{U} / \partial \mathrm{l}_{\mathrm{f}}}{\partial \mathrm{U} / \partial \mathrm{m}}=\gamma\left(\frac{\mathrm{m}}{\mathrm{l}_{\mathrm{f}}}\right)^{1+\mu}=\mathrm{w} \\
\mathrm{MRS}_{\mathrm{m}, \mathrm{l}_{\mathrm{e}}} & =\frac{\partial \mathrm{U} / \partial \mathrm{l}_{\mathrm{e}}}{\partial \mathrm{U} / \partial \mathrm{m}}=\beta\left(\frac{\mathrm{m}}{\mathrm{l}_{\mathrm{e}}}\right)^{1+\mu}=\mathrm{w}
\end{aligned}
$$

The equations (2) and (3) indicate that the MRS between any two components in the CES utility function does not depend on the third. By processing the above we obtain the following expressions:

$$
\begin{aligned}
& \log \left(\frac{m}{l_{\mathrm{f}}}\right)=\frac{1}{1+\mu} \log w-\frac{1}{1+\mu} \log \gamma \\
& \log \left(\frac{\mathrm{m}}{\mathrm{l}_{\mathrm{s}}}\right)=\frac{1}{1+\mu} \log \mathrm{w}-\frac{1}{1+\mu} \log \beta
\end{aligned}
$$

The unobservable and observable factors that have an impact on leisure activities are captured through the parameters $\beta$ and $\gamma$ as follows:

$$
\begin{aligned}
& \beta=\mathrm{e}^{\left(\mathrm{Z}_{\mathrm{f}} \theta_{\mathrm{f}}+\varphi_{\mathrm{f}}\right)} \\
& \gamma=\mathrm{e}^{\left(\mathrm{Z}_{\mathrm{f}} \theta_{\mathrm{f}}+\varphi_{\mathrm{f}}\right)}
\end{aligned}
$$

Where $\mathrm{Z}_{\mathrm{f}}$ and $\mathrm{Z}_{\mathrm{e}}$ represent different socio-economic variables that have an impact on utility and leisure time activities and $\varphi_{\mathrm{f}}$ and $\varphi_{\mathrm{e}}$ are random variables accounting for unobservable factors. Assuming that $\varphi_{\mathrm{f}}$ and $\varphi_{\mathrm{e}}$ are distributed as a bivariate normal distribution with zero means and constant variances, the linear system can be estimated using the bivariate probit method.

$$
\begin{aligned}
& \log \mathrm{l}_{\mathrm{f}}=\log \mathrm{m}-\frac{1}{1+\mu} \log \mathrm{w}+\frac{1}{1+\mu}\left(\mathrm{Z}_{\mathrm{f}} \theta_{\mathrm{f}}+\varphi_{\mathrm{f}}\right) \\
& \log \mathrm{l}_{\mathrm{e}}=\log \mathrm{m}-\frac{1}{1+\mu} \log \mathrm{w}+\frac{1}{1+\mu}\left(\mathrm{Z}_{\mathrm{e}} \theta_{\mathrm{e}}+\varphi_{\mathrm{e}}\right)
\end{aligned}
$$

The equations indicate that incomes should have a positive impact on the demand for fanatic and energetic sport demand and hourly wages a negative influence due to the opportunity cost of lost income.

Hourly wages are replaced with person's education and gender due to missing data ${ }^{3}$. However, the variables $\left(l_{\mathrm{f}}\right.$ or $\left.l_{\mathrm{e}}\right)$ on the left hand side of equations (8) and (9) are either one or zero (participate or not) and the equations are linearized:

$$
\begin{gathered}
l_{\mathrm{f}}^{*}=\mathrm{x}_{\mathrm{f}}^{\prime} \vartheta_{\mathrm{f}}+\varphi_{\mathrm{f}}, \mathrm{l}_{\mathrm{f}}=1 \text { if } \mathrm{l}_{\mathrm{f}}^{*}>0 \text { otherwise, } \\
\mathrm{l}_{\mathrm{e}}^{*}=\mathrm{x}_{\mathrm{e}}^{\prime} \vartheta_{\mathrm{e}}+\varphi_{\mathrm{e}}, \mathrm{l}_{\mathrm{e}}=1 \text { if } \mathrm{l}_{\mathrm{e}}^{*}>0 \text { otherwise, } \\
\mathrm{E}\left(\varphi_{\mathrm{f}} \mid \mathrm{x}_{\mathrm{f}}, \mathrm{x}_{\mathrm{e}}\right)=\mathrm{E}\left(\varphi_{\mathrm{e}} \mid \mathrm{x}_{\mathrm{f}}, \mathrm{x}_{\mathrm{e}}\right)=0
\end{gathered}
$$

${ }^{3}$ Maczulskij and Pehkonen (2011) show that among others education and gender have an impact on wages. 


$$
\begin{aligned}
\operatorname{Var}\left(\varphi_{\mathrm{f}} \mid \mathrm{x}_{\mathrm{f}}, \mathrm{x}_{\mathrm{e}}\right)=\operatorname{Var}\left(\varphi_{\mathrm{e}} \mid \mathrm{x}_{\mathrm{f}}, \mathrm{x}_{\mathrm{e}}\right)=1 \\
\operatorname{Cov}\left(\varphi_{\mathrm{f}}, \varphi_{\mathrm{e}} \mid \mathrm{x}_{\mathrm{f}}, \mathrm{x}_{\mathrm{e}}\right)=\rho
\end{aligned}
$$

A bivariate probit model explaining sport participation, both fanatic (attending sporting events) and energetic (exercising yourself) sport participation is estimated first. The socio-economic variables - age, the bodymass index, the educational level, gender and marital status and incomes - are used as explanatory variables 34 estimations in each country. Some of the variables are not available for each county, for example the body-mass index is usually not available.

The bivariate probit analysis assumes that the fanatic and energetic participations are interrelated and the error terms $\mathrm{u}_{1}$ and $\mathrm{u}_{2}$ in the explanation models are jointly bivariate distributed $\mathrm{N}(0,1)$. The coefficients in the probit model are difficult to interpret because they present the effects of the variables on the unobserved dependent variable $\mathrm{y}^{*}{ }_{1}$. However, the marginal effects of the explanatory variables are on the observed variable $y_{1}$. The total marginal effect could be separated into two portions as follows: the direct marginal effect and the indirect marginal effect where the latter portion is formed through the correlation coefficient of the error terms.

The second step is to analyze the marginal effects of gender using Hofstede's cultural dimensions. The estimated direct marginal effects are related with fanatic participation in sports and the indirect marginal effects are related with energetic participation in sports. Since we have 34 countries in the sample, the number of estimated direct and indirect marginal effects of gender is 34, respectively. There are substantial differences across countries and these coefficients are then regressed using Hofstede's cultural dimensions as regressors. Since fanatic and energetic sporting behaviour are interrelated, we use SURE method.

\section{Results}

In the first stage the bivariate probit analysis explaining fanatic and energetic sport participation is carried out. As an example the results for Finland and Argentina are presented in Tables 4 and Table 5. Since only dichotomous variables can used in the left hand side in the bivariate probit analysis, the original five valued variable is recoded into two: "never" isencoded 0 and the rest 1 ("daily", "several times a week ", "several times a month" or "several times a year of less often") ${ }^{4}$. This is on the left of Table 4 (titled fanatic2 or energetic2). In Finland $0.3 \%$ were "daily" attending a sport event as a spectator and 1.3\% "several times a week" in 2007. The biggest category was "several times a year or less often" (52.3\%) and roughly $40 \%$

\footnotetext{
${ }^{4} \mathrm{An}$ ordinal probit analysis might be more useful in explaining five valued variable, however, we assume that energetic and fanatic sport participation are interrelated and therefore bivariate probit is more useful.
} 
"never" attended a sport event as a spectator. On the right of Table 4 the coding is different: "daily", "several times a week" or "several times a month" are encoded 1 and two remaining" "several times a year or less often" or "never" are encoded 0 (titled fanatic3 and energetic3). In Finland $22.6 \%$ were "daily" physically active and $41.1 \%$ were active at "several times a week". Only $2.1 \%$ in the sample were "never" physically active in 2007.

Table 4. Bivariate Probit Analysis Results for Finland

\begin{tabular}{|l|l|l|l|l|}
\hline Finland, n=1314 & $\begin{array}{l}\text { D0.3/W1.3/M6.2/ } \\
\text { L52.3/N39.8 }\end{array}$ & $\begin{array}{l}\text { D22.6/W41.1/M20.5 } \\
\text { L13.8/N2.1 }\end{array}$ & & \\
\hline & $\begin{array}{l}\text { fanatic2 } \\
(60.1 / 39.8)\end{array}$ & energetic2 $(98.0 / 2.1)$ & $\begin{array}{l}\text { fanatic3 } \\
(7.8 / 92.1)\end{array}$ & $\begin{array}{l}\text { energetic3 } \\
(84.2 / 15.9)\end{array}$ \\
\hline BMI & -0.00378 & -0.0142 & 0.0102 & $-0.0139^{*}$ \\
\hline Female & $-0.573^{* * *}$ & $0.383^{*}$ & $-0.251^{*}$ & $0.211^{*}$ \\
\hline Age15-24 & 0.259 & 0.854 & -0.0208 & $0.408^{*}$ \\
\hline Age25-34 & 0.0151 & 0.256 & -0.0566 & $0.338^{*}$ \\
\hline Age45-54 & -0.138 & 0.102 & -0.186 & 0.214 \\
\hline Age55-64 & $-0.352^{* *}$ & 0.0436 & $-0.362^{*}$ & 0.179 \\
\hline Age65- & $-0.660^{* * *}$ & -0.116 & $-0.798^{*}$ & $\left.0.286^{*}\right)$ \\
\hline Edu1 & 0.191 & -0.215 & 0.421 & -0.310 \\
\hline Edu2 & 0.261 & -0.0840 & 0.264 & -0.178 \\
\hline Edu3 & 0.285 & 0.343 & 0.468 & 0.0285 \\
\hline Edu4 & $0.451^{* *}$ & 0.228 & 0.474 & 0.0217 \\
\hline Edu5 & 0.259 & 0.142 & 0.0433 & $0.401^{(*)}$ \\
\hline Married & $0.404^{*}$ & 0.00901 & 0.600 & 0.150 \\
\hline Divorced & 0.183 & -0.247 & 0.131 & 0.0708 \\
\hline Single & 0.275 & -0.00777 & 0.582 & 0.123 \\
\hline StdInc & $0.0204^{* *}$ & $0.0322^{*}$ & -0.00894 & -0.000525 \\
\hline & Area dummies & & $\begin{array}{l}\text { Area } \\
\text { dummies }\end{array}$ & \\
\hline & & & rho=0.138 (n.s.) \\
\hline
\end{tabular}

Noted: $\mathrm{n}=1314, \mathrm{D}=$ "daily", $\mathrm{W}=$ "several times a week", $\mathrm{M}=$ "several times of month", $\mathrm{L}=$ "several times a year of less often", $\mathrm{N}=$ "never". In fanatic2 the share of 0 is $60.1 \%$ and the share of 1 is $39.8 \%$ and respectively.

Source: Authors' estimations.

The bivariate probit analysis results reveal that gender is important. Females are less active fanatic sport participants and more active physically in Finland. The effect of age cohorts is as expected. Younger are more fanatic and more physically active. The educational level has a minor role in explaining sport participation. The standardised income effect is positive for both fanatic and energetic behaviour in the left estimations ("never" is encoded 0). The standardised income variable is created by dividing the household incomes with the size of the household. The logarithm of the previous ratio is used in estimations. On the right of Table 4, the income variable is not statistically significant. In these estimations both "never" and "several times a year or less often" are encoded 0 . The results indicate that standardised incomes are not able separate "several times a year or less often" sport participation from more active ("daily", "several times a week" or "several times a month") participation, but totally physically not active or totally non-attendees can be 
separated using the income variable. Next the same results for Argentina are presented below in Table 5:

Table 5. Bivariate probit analysis results for Argentina

\begin{tabular}{|l|l|l|l|l|}
\hline Argentina, $\mathbf{n = 1 6 4 8}$ & $\begin{array}{l}\text { D0.1/W5.3/M12.1/ } \\
\text { L14.0/N67.9 }\end{array}$ & $\begin{array}{l}\text { D12.5/W21.7/M12.1/ } \\
\text { L9.6/N44.2 }\end{array}$ & & \\
\hline & $\begin{array}{l}\text { fanatic2 } \\
(32.1 / 67.9)\end{array}$ & $\begin{array}{l}\text { energetic2 } \\
(55.8 / 44.2)\end{array}$ & $\begin{array}{l}\text { fanatic3 } \\
(17.5 / 82.5)\end{array}$ & $\begin{array}{l}\text { energetic3 } \\
(46.3 / 53.7)\end{array}$ \\
\hline BMI & not & not & not & not \\
\hline Female & $-0.857^{* * *}$ & $-0.260^{* * *}$ & $-0.750^{* * *}$ & $-0.210^{* *}$ \\
\hline Age15-24 & $0.292^{*)}$ & $0.523^{* *}$ & 0.131 & $0.402^{*}$ \\
\hline Age25-34 & -0.0892 & $0.184^{*}$ & $-0.185^{(*)}$ & 0.131 \\
\hline Age45-54 & -0.159 & 0.00603 & -0.132 & 0.0467 \\
\hline Age55-64 & $-0.249^{*}$ & 0.147 & $-0.394^{* *}$ & $0.198^{*}$ \\
\hline Age65- & $-0.484^{* *}$ & -0.0686 & $-0.325^{(*)}$ & 0.107 \\
\hline Edu1 & -0.601 & 0.0877 & -0.609 & -0.0518 \\
\hline Edu2 & -0.324 & 0.321 & -0.379 & 0.159 \\
\hline Edu3 & -0.240 & 0.502 & -0.378 & 0.324 \\
\hline Edu4 & -0.0382 & $0.837^{(*)}$ & -0.300 & 0.539 \\
\hline Edu5 & -0.275 & $0.934^{*}$ & -0.713 & 0.450 \\
\hline Married & -0.154 & -0.0691 & -0.0379 & -0.0473 \\
\hline Divorced & -0.175 & -0.132 & -0.0948 & -0.0320 \\
\hline Single & -0.179 & -0.0643 & 0.0239 & 0.0499 \\
\hline StdInc & -0.0100 & 0.00210 & -0.00860 & 0.000335 \\
\hline & Area dummies & & $\begin{array}{l}\text { Area } \\
\text { dummies }\end{array}$ & \\
\hline & & rho=0.290*** \\
\hline
\end{tabular}

Note: $\mathrm{n}=1648, \mathrm{D}=$ "daily", $\mathrm{W}=$ "several times a week", $\mathrm{M}=$ "several times of month", $\mathrm{L}=$ "several times a year of less often", $\mathrm{N}=$ "never". In fanatic2 the share of 0 is $32.1 \%$ and the share of 1 is $67.9 \%$ and respectively.

Source: Authors' estimations.

In Argentina $0.1 \%$ were attending a sport event as a spectator and 5.3\% "several times a week" in 2007. The biggest category was "never" with $67.9 \%$ in the sample $(n=1648)$. Almost $45 \%$ were not physically active at all in Argentina which is a substantially higher share than in Finland. The results show that men are both physically more active and are attending a sport event as a spectator. This is different in Finland where women are physically more active. The body-mass index (BMI) is not available for Argentina. The results indicate that there are differences in sport participation depending on gender and the country. Cultural differences exist.

The second step is to evaluate the marginal effects of gender on fanatic sport participation. The direct marginal effect must be assessed in relation to zero alternatives, (male). The indirect effect is formed through the correlation coefficient of the error term in the bivariate probit model. For Finland, the total marginal effect of gender (female) on fanatic sport participation is -0.233 . The direct effect is -0.224 and the indirect -0.009 in the case of "never" encoded 0 (on the left of Table 4). In the case of "never" and "several times a year or less often" encoded 0 (on the right of Table 4) the direct marginal effect of gender is -0.0324 and the indirect part is -0.0013 . The corresponding values for 
Argentina are -0.316 (total), -0.334 (direct) and 0.018 (indirect) if only "never" is encoded 0 (on the left of Table 5), and -0.215 (total), -0.227 (direct) and 0.012 (indirect) on the right of Table 5. Since in Finland the indirect marginal effect has a different sign than the direct effect has, the fanatic sport participation and energetic sport participation can be separated by gender. The opposite is true in Argentina where men are more fanatic and physically active sport participants.

A SURE method is used to evaluate the direct and indirect marginal effects of gender. The Hofstede (2011) dimensions and gross national income (logarithm) are used in the estimation as explanatory variables (Table 6):

Table 6. SURE Analysis of Direct and Indirect Marginal Effects of Gender on Fanatic Sporting Behaviour

\begin{tabular}{|l|l|l|}
\hline & Direct effect & Indirect effect \\
\hline log GNI & 0.061736 & $-0.020544^{*} *$ \\
& $(0.044740)$ & $(0.007836)$ \\
\hline Power distance & -0.000770 & -0.000034 \\
& $(0.001020)$ & $(0.000179)$ \\
\hline Individualism & $-0.00179^{*}$ & -0.000174 \\
& $(0.000785)$ & $(0.000137)$ \\
\hline Masculinity & 0.000822 & -0.000153 \\
& $(0.000694)$ & $(0.000122)$ \\
\hline Uncertainty Avoidance & $-0.001748^{*}$ & -0.000123 \\
& $(0.000913)$ & $(0.000160)$ \\
\hline Pragmatism & -0.000743 & -0.000272 \\
& $(0.000988)$ & $(0.000173)$ \\
\hline Indulgence & -0.000246 & $-0.000318^{*}$ \\
& $(0,000883)$ & $(0.000155)$ \\
\hline Constant & -0.600515 & $0.275418^{* * *}$ \\
& $(0.441541)$ & $(0.077338)$ \\
\hline $\mathbf{R}^{\mathbf{2}}$ & 0.144827 & 0.495907 \\
\hline $\mathbf{F}$ & 1.80 & 5.64 \\
\hline$\chi^{\mathbf{2}}$ & 22.55 & 40.52 \\
\hline $\mathbf{n}=\mathbf{3 4}$ & \multicolumn{2}{|}{} \\
\hline
\end{tabular}

Source: Authors' estimations.

The second step results show that individualism and uncertainty avoidance have an effect on direct marginal effect obtained from the first step. Hence in countries that are more individualistic (the person comes first; they have a high degree of self-respect and independence) and there are higher uncertainty avoidance (members of a culture feel threatened by ambiguous or unknown situations) men are more active in fanatic sport participation. If the culture of a country is more collectivist and there are weak uncertainty avoidance the gender differences in fanatic behaviour are lower.

The indirect marginal effect of gender is related to energetic sporting behaviour, or physical exercising. The gross national income per capita has a negative and significant sign indicating that in relatively rich countries women are physically more active. The indulgence variable is significant showing that women are physically more active in countries where positive emotions and freedom of speech are important. 
In the Table 6, the variables to be explained are the direct and indirect marginal effects of gender on sporting behaviour in the case of only "never" encoded 0 and all other alternatives encoded 1 ("daily", "several times a week", "several times a month" or "several times a year of less often"). In the case of "never" or "several times a year or less often"encoded 0 and the rest are encoded 1, the results are somewhat different. Individualism is significant in explaining the direct marginal effect and gross national income per capita is significant in explaining the indirect marginal effect of gender. Uncertainty avoidance and indulgence are not significant.

\section{Conclusions}

The purpose of this study is to understand cultural differences across nations in fanatic and energetic sport participation. Football is one of the most popular sports in terms of the spectator number, however, in some countries a football game is not the top-rated sporting event. In Finland roughly $17 \%$ of the adult populations have attended a football game as a spectator in 2005 - 2006, but ice hockey is more popular, the share is more than $25 \%$. Finland is one of the best in international ice hockey since the Finnish national team has won the world championship twice (1995 and 2011), but the FIFA ranking in football is about 50. Each country has its own top sport. A wide range of factors leads to international sporting success. The first studies on the factors leading to international success were carried out in the 1950's and 1960's. Jokl (1964) showed that socio-economic factors, like mortality and GNP per capital have an impact on success in the Olympic Games held at Helsinki 1952 and Rome 1960. De Bosscher et al. (2006) classify top-level success into macro - meso micro-level determinants. The macro-level determinants are: economic welfare, population, geographic and climatic variation, degree of urbanization, political system and cultural system. These macro-level determinants can also explain individual sport participation. In this study cultural dimensions as Hofstede these define are used to explain fanatic and energetic sporting behaviour.

Among the fans different clusters can be found, for example British rugby fans are more likely middle-class in comparison to soccer fans who belong to working class (Pope 2013). Here the upper class, middle-class, working class dimension has been taken into account by using a household income variable in the first step estimations as well as the educational level, marital status and gender that have been found significant in explaining sporting behavior. The first step used bivariate probit analysis to understand both the fanatic and energetic sport participation. The resulting marginal effects of gender are used in the second step where both the direct marginal and indirect marginal effects are evaluated using the cultural dimensions and economic wealth as explanatory variables. The cultural dimensions are based on Hofstede's worldwide studies.

The second step analysis reveals that individualism, uncertainty avoidance and indulgence are the dimensions that significantly explain gender differences 
in sporting behaviour. Hofstede's framework composes a simple and practical short cut to the integration of culture into studies. The SURE results show that high individualism has diminishing effect on direct fanatic behavior of women. Since Finland is a rather individualist country, men are more active in the audience of a sporting event. Finland also has a high preference for avoiding uncertainty that is lowering effect on the fanatic behavior of women. The indulgence dimension in Finland indicating that people have a positive attitude and the leisure time is important. This has a positive impact on the energetic behavior of women.

\section{Acknowledgements}

I wish to thank anonymous reviewers and professor Gregory T. Papanikos for helpful comments. All errors are mine. 


\section{Appendix}

Probity Analysis Results

\begin{tabular}{|c|c|c|c|c|}
\hline Austria, $n=1016$ & SpPas111 & SpAct111 & SpPas110 & SpAct110 \\
\hline BMI & 0.00443 & $0.0211 * * *$ & -0.000460 & $0.0234 * * *$ \\
\hline Female & $-0.500 * * *$ & -0.000383 & $-0.459 * * *$ & $0.209 *$ \\
\hline Age15-24 & $0.312^{(*)}$ & 0.219 & $0.288^{(*)}$ & 0.152 \\
\hline Age25-34 & 0.127 & -0.174 & $0.258^{(*)}$ & 0.0487 \\
\hline Age45-54 & $-0.244^{(*)}$ & -0.120 & -0.163 & 0.0533 \\
\hline Age55-64 & $-0.617 * * *$ & -0.0612 & -0.260 & 0.151 \\
\hline Age65- & $-0.915 * * *$ & $-0.630 * *$ & $-1.041 * * *$ & -0.0996 \\
\hline \multicolumn{5}{|l|}{ Edu1 } \\
\hline Edu2 & 0.120 & 0.0744 & -0.153 & -0.0814 \\
\hline Edu3 & $0.551 * *$ & $0.651 * *$ & 0.131 & $0.345^{*}$ \\
\hline Edu4 & 0.211 & $1.018 * * *$ & -0.221 & $0.530 * *$ \\
\hline Edu5 & 0.196 & $0.676 * *$ & $-0.0843 * * *$ & $0.772 * * *$ \\
\hline Married & 0.325 & 0.650 ** & $0.625^{(*)}$ & $0.500 * *$ \\
\hline Divorced & 0.00821 & 0.241 & 0.442 & $0.378^{(*)}$ \\
\hline Single & -0.00669 & $0.521 *$ & 0.414 & $0.557 * *$ \\
\hline \multirow[t]{3}{*}{ StdInc } & $0.0537 * * *$ & $0.0480^{*}$ & $0.0525 * *$ & $0.0268^{(*)}$ \\
\hline & Area dummies & & Area dummies & \\
\hline & \multicolumn{2}{|l|}{ rho $=0.732 * * *$} & \multicolumn{2}{|l|}{ rho $=0.380 * * *$} \\
\hline & & & & \\
\hline
\end{tabular}

\begin{tabular}{|c|c|c|c|c|}
\hline Australia, $n=2613$ & SpPas111 & SpAct111 & SpPas110 & SpAct110 \\
\hline BMI & not & not & not & not \\
\hline Female & $-0.261 * * *$ & $0.113^{(*)}$ & $-0.148^{*}$ & $0.0882^{(*)}$ \\
\hline Age15-24 & -0.172 & 0.00386 & $-0.219^{(*)}$ & 0.0241 \\
\hline Age25-34 & $-0.253 * *$ & -0.0826 & $-0.255^{*}$ & -0.0390 \\
\hline Age45-54 & $-0.191 *$ & -0.0813 & $-0.171^{(*)}$ & -0.107 \\
\hline Age55-64 & $-0.399 * * *$ & $-0.242 *$ & $-0.490 * * *$ & -0.132 \\
\hline Age65- & $-0.604 * * *$ & $-0.330 * *$ & $-0.631 * * *$ & -0.0631 \\
\hline Edu1 & 0.04154 & 0.124 & -0.117 & -0.0328 \\
\hline Edu2 & $0.316^{(*)}$ & 0.308 & 0.115 & 0.0854 \\
\hline Edu3 & $0.443 *$ & $0.613 * *$ & 0.181 & $0.398 *$ \\
\hline Edu4 & $0.332 *$ & $0.591 * *$ & 0.0145 & $0.357 *$ \\
\hline Edu5 & $0.503 * *$ & $0.801 * * *$ & -0.0200 & $0.640 * * *$ \\
\hline Married & 0.136 & 0.192 & -0.0882 & 0.0763 \\
\hline Divorced & -0.0375 & 0.0231 & -0.156 & -0.0581 \\
\hline Single & 0.131 & $0.275^{(*)}$ & -0.219 & $0.226^{(*)}$ \\
\hline \multirow[t]{4}{*}{ StdInc } & $0.0135^{* *}$ & $0.0251 * * *$ & 0.00422 & $0.0127 *$ \\
\hline & Area dummies & & Area dummies & \\
\hline & \multicolumn{2}{|l|}{ rho $=0.502 * * *$} & \multicolumn{2}{|l|}{ rho $=0.239 * * *$} \\
\hline & & & & \\
\hline
\end{tabular}




\begin{tabular}{|c|c|c|c|c|}
\hline Belgium, $n=1233$ & SpPas111 & SpAct111 & SpPas110 & SpAct110 \\
\hline BMI & not & not & not & not \\
\hline Female & $-0.436 * * *$ & 0.0490 & $-0.436 * * *$ & -0.0483 \\
\hline Age15-24 & 0.209 & $0.523^{*}$ & 0.172 & $0.365^{*}$ \\
\hline Age25-34 & -0.0465 & 0.0872 & -0.151 & -0.0920 \\
\hline Age45-54 & $-0.257 *$ & $-0.271^{(*)}$ & $-0.304 *$ & $-0.241 *$ \\
\hline Age55-64 & $-0.428 * * *$ & -0.205 & $-0.651 * * *$ & -0.158 \\
\hline Age65- & $-0.669 * * *$ & $-0.661 * * *$ & $-0.628 * * *$ & $-0.427 * *$ \\
\hline Edu1 & -0.189 & -0.105 & -0.0346 & -0.0519 \\
\hline Edu2 & -0.123 & 0.0959 & $-0-168$ & 0.0269 \\
\hline Edu3 & -0.0906 & 0.407 & -0.183 & 0.254 \\
\hline Edu4 & 0.0320 & $0.806 * *$ & -0.366 & $0.567 *$ \\
\hline Edu5 & -0.0884 & $1.222 * * *$ & -0.0496 & $0.820 * *$ \\
\hline Married & $0.482 *$ & 0.176 & 0.308 & 0.151 \\
\hline Divorced & 0.346 & -0.0178 & 0.176 & -0.0410 \\
\hline Single & 0.351 & 0.172 & 0.106 & 0.215 \\
\hline \multirow[t]{5}{*}{ StdInc } & $0.0224 *$ & -0.000296 & $0.0309 *$ & -0.0101 \\
\hline & Area dummies & & Area dummies & \\
\hline & \multicolumn{2}{|l|}{ rho $=0.355 * * *$} & \multicolumn{2}{|l|}{ rho $=0.200 * * *$} \\
\hline & & & & \\
\hline & & & & \\
\hline
\end{tabular}

\begin{tabular}{|c|c|c|c|c|}
\hline Bulgaria, $n=953$ & SpPas111 & SpAct111 & SpPas110 & SpAct110 \\
\hline BMI & 0.000 & -0.000 & -0.000 & 0.000 \\
\hline Female & $-0.720 * * *$ & -0.0831 & $-0.404 * *$ & $-0.169^{(*)}$ \\
\hline \multicolumn{5}{|l|}{ Age15-24 } \\
\hline \multicolumn{5}{|l|}{ Age25-34 } \\
\hline Age45-54 & -0.162 & $-0.352 * *$ & $-0.419 *$ & $-0.552 * * *$ \\
\hline Age55-64 & -0.212 & $-0.224^{(*)}$ & -0.185 & $-0.298 *$ \\
\hline Age65- & $-0.540 * * *$ & $-0.441 * *$ & $-0.445^{*}$ & $-0.457 * *$ \\
\hline \multicolumn{5}{|l|}{ Edu1 } \\
\hline \multicolumn{5}{|l|}{ Edu2 } \\
\hline Edu3 & $0.491 * * *$ & $0.747 * * *$ & 0.269 & $0.543 * * *$ \\
\hline Edu4 & $0.725 * * *$ & $1.221 * * *$ & 0.317 & $0.848 * * *$ \\
\hline Edu5 & $0.968 *$ & $1.610 * *$ & 0.255 & $0.766^{*}$ \\
\hline \multicolumn{5}{|l|}{ Married } \\
\hline \multicolumn{5}{|l|}{ Divorced } \\
\hline Single & $0.320 *$ & $0.498 * * *$ & 0.217 & $0.428 * *$ \\
\hline \multirow[t]{4}{*}{ StdInc } & $-0.0535 * *$ & $-0.0389 *$ & -0.0236 & $-0.0434 *$ \\
\hline & Area dummies & & Area dummies & \\
\hline & \multicolumn{2}{|l|}{ rho $=0.628 * * *$} & \multicolumn{2}{|l|}{ rho $=0.536^{* * *}$} \\
\hline & & & & \\
\hline
\end{tabular}




\begin{tabular}{|c|c|c|c|c|}
\hline Chile, $n=1498$ & SpPas111 & SpAct111 & SpPas110 & SpAct110 \\
\hline BMI & not & not & not & not \\
\hline Female & $-0.953 * * *$ & $-0.434 * * *$ & $-0.763 * * *$ & $-0.383 * * *$ \\
\hline Age15-24 & 0.147 & 0.204 & 0.225 & $0.306 *$ \\
\hline Age25-34 & $0.281^{*}$ & 0.180 & $0.251^{*}$ & $0.213^{*}$ \\
\hline Age45-54 & 0.0192 & -0.123 & 0.117 & -0.0778 \\
\hline Age55-64 & $-0.441 * *$ & -0.168 & -0.139 & -0.0414 \\
\hline Age65- & $-0.480 * *$ & -0.130 & $-0.529 * *$ & -0.0834 \\
\hline Edu1 & 0.323 & 0.0649 & 0.486 & 0.132 \\
\hline Edu2 & 0.502 & 0.317 & 0.500 & 0.325 \\
\hline Edu3 & $0.618^{(*)}$ & $0.503 *$ & 0.628 & $0.453^{(*)}$ \\
\hline Edu4 & $0.862 * *$ & $0.871 * * *$ & 0.787 & $0.696 * *$ \\
\hline Edu5 & $0.728 *$ & $0.755 * *$ & 0.520 & $0.703 * *$ \\
\hline Married & 0.0851 & 0.0822 & 0.103 & 0.0304 \\
\hline Divorced & 0.0257 & -0.0828 & 0.0836 & 0.0450 \\
\hline Single & 0.0908 & 0.183 & 0.0941 & 0.177 \\
\hline \multirow[t]{4}{*}{ StdInc } & 0.0140 & 0.0143 & 0.0144 & 0.00985 \\
\hline & Area dummies & & Area dummies & \\
\hline & \multicolumn{2}{|l|}{ rho $=0.521 * * *$} & \multicolumn{2}{|l|}{ rho $=0.506 * * *$} \\
\hline & & & & \\
\hline
\end{tabular}

\begin{tabular}{|l|l|l|l|l|}
\hline Taiwan, n=2147 & SpPas111 & SpAct111 & SpPas110 & SpAct110 \\
\hline BMI & not & not & not & not \\
\hline Female & $-0.451^{* * *}$ & 0.0280 & & \\
\hline Age15-24 & $0.511^{* * *}$ & $0.382^{*}$ & & \\
\hline Age25-34 & 0.150 & 0.0634 & & \\
\hline Age45-54 & -0.0390 & $0.270^{*}$ & & \\
\hline Age55-64 & $-0.245^{(*)}$ & $0.417^{* *}$ & & \\
\hline Age65- & $-0.316^{*}$ & $0.567^{* * *}$ & & \\
\hline Edu1 & $0.524^{*}$ & 0.127 & & \\
\hline Edu2 & 0.372 & $0.382^{*}$ & & \\
\hline Edu3 & $0.768^{* *}$ & $1.031^{* * *}$ & & \\
\hline Edu4 & $0.879^{* * *}$ & $1.441^{* * *}$ & & \\
\hline Edu5 & $1.080^{* * *}$ & $1.603^{* * *}$ & & \\
\hline Married & not & not & & \\
\hline Divorced & not & not & & \\
\hline Single & not & not & & \\
\hline StdInc & $0.0206^{*}$ & $0.014^{(*)}$ & & \\
\hline & Area dummies & & Area dummies & \\
\hline & rho=0.394*** & & & \\
\hline & & & & \\
\hline & & & & \\
\hline
\end{tabular}




\begin{tabular}{|c|c|c|c|c|}
\hline Croatia, $n=1190$ & SpPas111 & SpAct111 & SpPas110 & SpAct110 \\
\hline BMI & not & not & not & not \\
\hline Female & $-0.815 * * *$ & $-0.264 * *$ & $-0.792 * * *$ & $-0.219 * *$ \\
\hline Age15-24 & $0.565 * * *$ & $0.375^{*}$ & 0.212 & $0.301^{(*)}$ \\
\hline Age25-34 & $0.360 * *$ & $0.267^{(*)}$ & 0.0510 & $0.309 *$ \\
\hline Age45-54 & 0.0302 & -0.0245 & -0.137 & 0.0180 \\
\hline Age55-64 & $-0.539 * * *$ & -0.189 & $-0.314^{(*)}$ & 0.0390 \\
\hline Age65- & $-0.507 * * *$ & $-0.259^{(*)}$ & $-0.300^{(*)}$ & -0.0918 \\
\hline Edu1 & 0.0251 & $0.756 * * *$ & 0.0589 & $0.663^{* *}$ \\
\hline Edu2 & $0.374^{(*)}$ & $0.951 * * *$ & 0.184 & $0.919 * * *$ \\
\hline Edu3 & $0.363^{(*)}$ & $1.278 * * *$ & 0.184 & $1.234 * * *$ \\
\hline Edu4 & $0.441^{(*)}$ & $1.262 * * *$ & 0.438 & $1.272 * * *$ \\
\hline Edu5 & $0.393^{(*)}$ & $1.445^{* * *}$ & 0.133 & $1.318^{* * * *}$ \\
\hline Married & 0.0699 & -0.131 & 0.161 & -0.145 \\
\hline \multicolumn{5}{|l|}{ Divorced } \\
\hline Single & 0.206 & 0.0174 & 0.122 & -0.0226 \\
\hline \multirow[t]{4}{*}{ StdInc } & 0.00336 & 0.00847 & 0.00466 & $0.0127^{(*)}$ \\
\hline & Area dummies & & Area dummies & \\
\hline & \multicolumn{2}{|l|}{ rho $=0.413 * * *$} & \multicolumn{2}{|l|}{ rho $=0.379 * * *$} \\
\hline & & & & \\
\hline
\end{tabular}

\begin{tabular}{|c|c|c|c|c|}
\hline Cyprus, n=994 & SpPas111 & SpAct111 & SpPas110 & SpAct110 \\
\hline BMI & not & not & not & not \\
\hline Female & $0.578 * * *$ & $-1.443 * * *$ & $0.646 * * *$ & $-1.290 * * *$ \\
\hline Age15-24 & -0.342 & 0.216 & -0.245 & 0.0504 \\
\hline Age25-34 & -0.0549 & -0.172 & -0.143 & -0.0973 \\
\hline Age45-54 & -0.0359 & -0.232 & -0.0539 & -0.293 \\
\hline Age55-64 & 0.212 & $-0.499 * *$ & 0.194 & $-0.796 * * *$ \\
\hline Age65- & $0.543^{*}$ & $-1.012 * * *$ & $0.668^{*}$ & $-0.789 *$ \\
\hline Edu1 & -0.0716 & -0.359 & -0.239 & -0.114 \\
\hline Edu2 & -0.493 & -0.253 & -0.449 & 0.114 \\
\hline Edu3 & -0.373 & -0.0857 & -0.296 & 0.0266 \\
\hline Edu4 & -0.545 & -0.111 & -0.647 & 0.181 \\
\hline Edu5 & -0.196 & 0.00731 & -0.153 & -0.104 \\
\hline Married & -0.153 & -0.0535 & -0.0867 & -0.104 \\
\hline Divorced & 0.153 & 0.111 & -0.0264 & -0.0995 \\
\hline Single & 0.0873 & 0.283 & $\begin{array}{l}-0.0841 \\
\end{array}$ & 0.201 \\
\hline \multirow{4}{*}{ StdInc } & -0.0114 & 0.00893 & -0.0114 & 0.0198 \\
\hline & Area dummies & & Area dummies & \\
\hline & \multicolumn{2}{|l|}{ rho $=0.287 * * *$} & \multicolumn{2}{|l|}{ rho $=0.293 * * *$} \\
\hline & & & & \\
\hline
\end{tabular}




\begin{tabular}{|c|c|c|c|c|}
\hline Czech, n=1212 & SpPas111 & SpAct111 & SpPas110 & SpAct110 \\
\hline BMI & not & not & not & not \\
\hline Female & $-0.957 * * *$ & -0.0993 & $-0.915^{* * *}$ & -0.0586 \\
\hline Age15-24 & 0.149 & 0.170 & 0.0101 & 0.364 \\
\hline Age25-34 & -0.231 & -0.0124 & -0.184 & 0.101 \\
\hline Age45-54 & $-0.352 *$ & -0.211 & -0.148 & -0.192 \\
\hline Age55-64 & $-0.573 * * *$ & $-0.425 * *$ & $-0.316^{(*)}$ & $-0.381 * *$ \\
\hline Age65- & $-1.070 * * *$ & $-0.611 * * *$ & $-0.664 * * *$ & $-0.400 * *$ \\
\hline Edu1 & -0.228 & $-1.164^{(*)}$ & 0.359 & -0.583 \\
\hline Edu2 & -0.0373 & -0.831 & 0.320 & -0.330 \\
\hline Edu3 & -0.0743 & -0.558 & 0.186 & -0.0664 \\
\hline Edu4 & -0.0719 & -0.261 & -0.331 & 0.149 \\
\hline Edu5 & -0.0672 & -0.274 & 0.537 & 0.317 \\
\hline Married & $0.288^{*}$ & 0.0575 & 0.175 & -0.0464 \\
\hline Divorced & -0.0260 & -0.119 & -0.104 & -0.202 \\
\hline Single & -0.327 & 0.218 & $0.466^{(*)}$ & 0.0984 \\
\hline \multirow[t]{4}{*}{ StdInc } & $0.00971^{(*)}$ & $0.0122^{(*)}$ & $0.0172 *$ & $0.0141 *$ \\
\hline & Area dummies & & Area dummies & \\
\hline & \multicolumn{2}{|l|}{ rho $=0.479 * * *$} & \multicolumn{2}{|l|}{ rho $=0.304 * * *$} \\
\hline & & & & \\
\hline
\end{tabular}

\begin{tabular}{|c|c|c|c|c|}
\hline Dominican, $n=2124$ & SpPas111 & SpAct111 & SpPas110 & SpAct110 \\
\hline BMI & -0.00433 & -0.000769 & -0.00422 & 0.00322 \\
\hline Female & $-0.508 * * *$ & $-0.323 * * *$ & $-0.299 * * *$ & $-0.294 * * *$ \\
\hline Age15-24 & 0.160 & 0.106 & 0.0526 & 0.136 \\
\hline Age25-34 & 0.0614 & $0.186^{*}$ & 0.0547 & $0.209 * *$ \\
\hline Age45-54 & -0.0551 & 0.0120 & 0.0816 & 0.0886 \\
\hline Age55-64 & $-0.472 * * *$ & -0.115 & $-0.397 * * *$ & -0.131 \\
\hline Age65- & $-0.461 * * *$ & $-0.253^{(*)}$ & $-0.310 * * *$ & -0.146 \\
\hline Edu1 & $0.228^{*}$ & $0.414 * * *$ & 0.0774 & $0.333 * * *$ \\
\hline Edu2 & $0.205^{*}$ & $0.365^{* * *}$ & 0.112 & $0.325 * * *$ \\
\hline Edu3 & $0.392 * * *$ & $0.609 * * *$ & $0.165^{*}$ & $0.450 * * *$ \\
\hline Edu4 & $0.420 * * *$ & $0.474 * * *$ & 0.106 & $0.424 * * *$ \\
\hline Edu5 & 0.172 & $0.475 * * *$ & 0.0262 & $0.409 * * *$ \\
\hline Married & $0.179 *$ & $0.131^{(*)}$ & $0.232 * *$ & $0.140^{(*)}$ \\
\hline Divorced & 0.144 & $0.162^{(*)}$ & 0.154 & $0.155^{(*)}$ \\
\hline Single & $0.227 * *$ & $0.261 * * *$ & $0.188^{*}$ & $0.200^{* *}$ \\
\hline \multirow[t]{4}{*}{ StdInc } & $0.0151^{(*)}$ & $0.0168^{*}$ & 0.00737 & 0.00372 \\
\hline & Area dummies & & Area dummies & \\
\hline & \multicolumn{2}{|l|}{ rho $=0.729 * * *$} & \multicolumn{2}{|l|}{ rho $=0.575 * * *$} \\
\hline & marginal eff (ir & mes) $=0 \mathrm{bu}$ & $t=0.00452^{(*)}$, in & rect $=-0.00252$ \\
\hline
\end{tabular}




\begin{tabular}{|c|c|c|c|c|}
\hline France, $n=1995$ & SpPas111 & SpAct111 & SpPas110 & SpAct110 \\
\hline BMI & 0.00506 & -0.00462 & -0.00161 & -0.00513 \\
\hline Female & $-0.578 * * *$ & $-0.140^{(*)}$ & $-0.414 * * *$ & -0.101 \\
\hline Age15-24 & 0.229 & $0.412^{(*)}$ & 0.205 & 0.150 \\
\hline Age25-34 & -0.0692 & -0.0178 & -0.0770 & $-0.183^{(*)}$ \\
\hline Age45-54 & $-0.249 * *$ & -0.0586 & -0.156 & -0.0503 \\
\hline Age55-64 & $-0.340 * * *$ & -0.0544 & $-0.305^{*}$ & 0.0866 \\
\hline Age65- & $-0.664 * * *$ & $-0.347 * *$ & -0.196 & -0.0777 \\
\hline Edu1 & 0.112 & $0.682 * *$ & 0.307 & $0.523 *$ \\
\hline Edu2 & 0.213 & $0.796^{* * *}$ & 0.348 & $0.748 * * *$ \\
\hline Edu3 & 0.207 & $0.655 * *$ & 0.413 & $0.550 *$ \\
\hline Edu4 & 0.192 & $0.947 * * *$ & 0.267 & $0.760 * * *$ \\
\hline Edu5 & 0.101 & $1.117 * * *$ & 0.0593 & $0.949 * * *$ \\
\hline Married & $0.325 * *$ & $0.283^{*}$ & 0.128 & 0.131 \\
\hline Divorced & $0.315^{*}$ & $0.270^{(*)}$ & 0.148 & 0.0979 \\
\hline Single & 0.0305 & 0.154 & -0.206 & 0.165 \\
\hline \multirow[t]{4}{*}{ StdInc } & 0.00307 & $0.0165^{(*)}$ & 0.0142 & 0.00377 \\
\hline & Area dummies & & Area dummies & \\
\hline & \multicolumn{2}{|l|}{ rho $=0.314 * * *$} & \multicolumn{2}{|l|}{ rho $=0.253 * * *$} \\
\hline & & & & \\
\hline
\end{tabular}

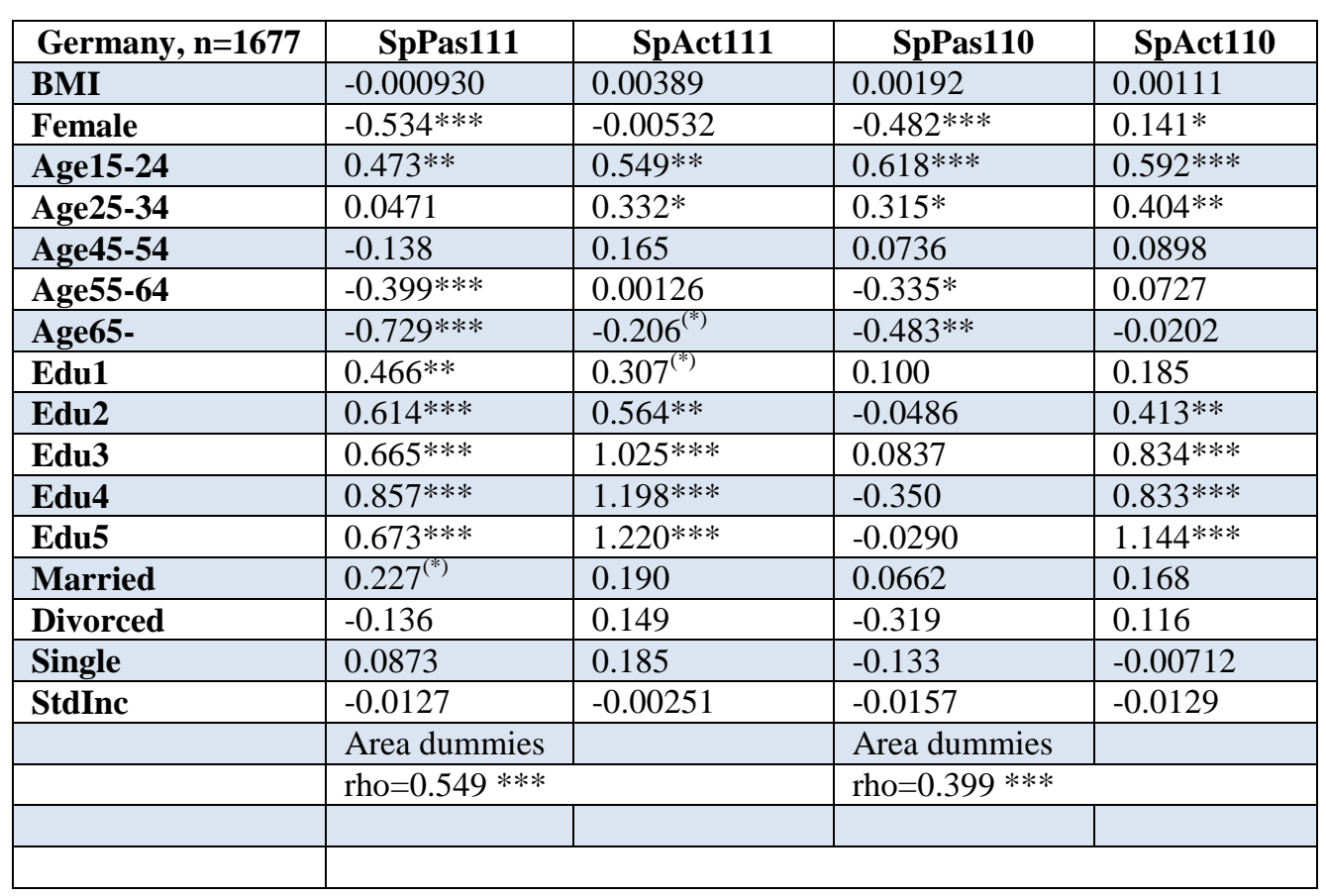




\begin{tabular}{|c|c|c|c|c|}
\hline Hungary, n=1013 & SpPas111 & SpAct111 & SpPas110 & SpAct110 \\
\hline \multicolumn{5}{|l|}{ BMI } \\
\hline Female & $-0.612 * * *$ & 0.0917 & $-0.482 * * *$ & 0.126 \\
\hline Age15-24 & $0.435 * *$ & $0.755^{* * * *}$ & 0.150 & $0.702 * * *$ \\
\hline Age25-34 & -0.166 & 0.0367 & -0.188 & 0.116 \\
\hline Age45-54 & $-0.380 * *$ & $-0.256^{(*)}$ & $-0.402 *$ & -0.0902 \\
\hline Age55-64 & $-0.436 * *$ & $-0.554 * * *$ & -0.185 & $-0.397 * *$ \\
\hline Age65- & $-0.868 * * *$ & $-0.442 * *$ & $-0.828 * * *$ & $-0.403 * *$ \\
\hline Edu1 & -0.131 & 0.328 & & \\
\hline Edu2 & 0.00327 & $0.578^{*}$ & & \\
\hline Edu3 & 0.393 & $1.030 * * *$ & & \\
\hline Edu4 & 0.385 & $1.325 * * *$ & & \\
\hline Edu5 & 0.495 & $1.733 * * *$ & & \\
\hline \multicolumn{5}{|l|}{ Married } \\
\hline \multicolumn{5}{|l|}{ Divorced } \\
\hline \multicolumn{5}{|l|}{ Single } \\
\hline \multirow[t]{4}{*}{ StdInc } & $0.0249 *$ & 0.0118 & -0.00801 & -0.00441 \\
\hline & Area dummies & & Area dummies & \\
\hline & \multicolumn{2}{|l|}{ rho $=0.406 * * *$} & \multicolumn{2}{|l|}{ rho $=0.306^{* * *}$} \\
\hline & & & & \\
\hline
\end{tabular}

\begin{tabular}{|c|c|c|c|c|}
\hline Ireland, $n=2005$ & SpPas111 & SpAct111 & SpPas110 & SpAct110 \\
\hline BMI & $0.0115 * * *$ & 0.00433 & $0.0162 * * *$ & 0.00357 \\
\hline Female & $-0.641 * * *$ & 0.0504 & $-0.387 * * *$ & 0.0795 \\
\hline Age15-24 & -0.0704 & $0.351 * *$ & 0.120 & $0.372 * *$ \\
\hline Age25-34 & $-0.179^{(*)}$ & $0.196^{(*)}$ & -0.0103 & 0.0628 \\
\hline Age45-54 & $-0.301 * *$ & 0.0147 & $-0.295 * *$ & -0.0788 \\
\hline Age55-64 & $-0.461 * * *$ & -0.101 & $-0-325 * *$ & -0.103 \\
\hline Age65- & $-0.665^{* * *}$ & $-0.345^{* *}$ & $-0.426^{* * *}$ & $-0.280 *$ \\
\hline Edu1 & 0.308 & 0.168 & 0.247 & 0.241 \\
\hline Edu2 & $0.518^{*}$ & $0.434^{*}$ & 0.329 & 0.477 \\
\hline Edu3 & $0.780 * * *$ & $0.702 * *$ & $0.474^{(*)}$ & $0.693 * *$ \\
\hline Edu4 & $0.921 * * *$ & $0.973^{* * *} *$ & $0.486^{(*)}$ & $0.901 * * *$ \\
\hline Edu5 & $0.872 * * *$ & $1.189 * * *$ & 0.388 & $1.236 * * *$ \\
\hline Married & $0.420 * * *$ & $0.336 * *$ & $0.300^{*}$ & $0.302 * *$ \\
\hline Divorced & 0.167 & $0.286^{(*)}$ & 0.162 & $0.347 *$ \\
\hline Single & $0.253 *$ & 0.166 & 0.146 & 0.142 \\
\hline StdInc & 0.00338 & 0.00838 & 0.00395 & 0.000437 \\
\hline & Area dummies & & Area dummies & \\
\hline & \multicolumn{2}{|l|}{ rho $=0.385^{* * *}$} & \multicolumn{2}{|l|}{ rho $=0.400 * * *$} \\
\hline
\end{tabular}




\begin{tabular}{|c|c|c|c|c|}
\hline Israel, $n=1330$ & SpPas111 & SpAct111 & SpPas110 & SpAct110 \\
\hline BMI & 0.00832 & 0.00248 & 0.00417 & -0.00283 \\
\hline Female & $-0.894 * * *$ & $-0.357 * * *$ & $-1.006^{* * *}$ & $-0.349 * * *$ \\
\hline Age15-24 & 0.0299 & $0.330 *$ & 0.0228 & $0.384 * *$ \\
\hline Age25-34 & 0.0330 & -0.0662 & 0.0783 & 0.0539 \\
\hline Age45-54 & 0.130 & 0.191 & 0.132 & 0.149 \\
\hline Age55-64 & 0.0682 & -0.0477 & 0.0462 & 0.0163 \\
\hline Age 65- & -0.0454 & -0.0931 & 0.0163 & 0.00358 \\
\hline Edu1 & -0.263 & -0.204 & $-0.437^{(*)}$ & -0.115 \\
\hline Edu2 & -0.0951 & 0.256 & -0.126 & 0.304 \\
\hline Edu3 & -0.0702 & $0.419 *$ & -0.276 & $0.368^{(*)}$ \\
\hline Edu4 & -0.118 & $0.408 *$ & -0.385 & $0.430 *$ \\
\hline Edu5 & -0.0581 & $0.701 * * *$ & -0.357 & $0.686 * * *$ \\
\hline Married & $0.344^{*}$ & 0.109 & $0.419 * *$ & 0.105 \\
\hline Divorced & 0.290 & 0.0444 & $0.482 *$ & 0.0304 \\
\hline Single & $0.622 * * *$ & $0.443^{*}$ & $0.569 * *$ & $0.312^{(*)}$ \\
\hline \multirow[t]{4}{*}{ StdInc } & 0.00507 & -0.00154 & -0.00814 & -0.0159 \\
\hline & Area dummies & & Area dummies & \\
\hline & \multicolumn{2}{|l|}{ rho $=0.367 * * *$} & \multicolumn{2}{|l|}{ rho $=0.223 * * *$} \\
\hline & & & & \\
\hline
\end{tabular}

\begin{tabular}{|l|l|l|l|l|}
\hline Japan, n=1214 & \multicolumn{1}{|c|}{ SpPas111 } & \multicolumn{1}{|c|}{ SpAct111 } & \multicolumn{1}{|c|}{ SpPas110 } & \multicolumn{1}{|c|}{ SpAct110 } \\
\hline BMI & & & & \\
\hline Female & -0.263 & $-0.146^{(*)}$ & -0.251 & -0.0890 \\
\hline Age15-24 & -0.545 & $0.321^{(*)}$ & -0.551 & $0.362^{*}$ \\
\hline Age25-34 & -0.357 & 0.0507 & -0.357 & 0.0278 \\
\hline Age45-54 & -0.306 & -0.0181 & -0.309 & 0.0397 \\
\hline Age55-64 & -0.0834 & 0.0833 & -0.0703 & $0.47 *^{*} *$ \\
\hline Age65- & -0.207 & $-0.264^{(*)}$ & -0.173 & $0.311^{*}$ \\
\hline Edu1 & -0.154 & -0.234 & -0.190 & -0.197 \\
\hline Edu2 & \multicolumn{5}{l}{} \\
\hline Edu3 & -0.334 & -0.0874 & -0.363 & -0.148 \\
\hline Edu4 & -0.185 & 0.112 & -0.201 & 0.0198 \\
\hline Edu5 & -0.572 & 0.279 & -0.610 & 0.0882 \\
\hline Married & -0.0683 & 0.0767 & -0.0667 & -0.0703 \\
\hline Divorced & 0.575 & 0.0184 & 0.562 & 0.0756 \\
\hline Single & 0.186 & 0.0233 & 0.188 & 0.117 \\
\hline StdInc & -0.0114 & $0.0379^{*}$ & -0.00850 & $0.0405^{* *}$ \\
\hline & Area dummies & & Area dummies & \\
\hline & rho=0.221 (n.s) & rho=0.345* & \\
\hline & & & & \\
\hline
\end{tabular}




\begin{tabular}{|c|c|c|c|c|}
\hline South Korea, n=1422 & SpPas111 & SpAct111 & SpPas110 & SpAct110 \\
\hline BMI & 0.00598 & $0.0262 * *$ & 0.0121 & $0.0270 * *$ \\
\hline Female & $-0.521 * * *$ & -0.0293 & $-0.588 * * *$ & -0.0818 \\
\hline Age15-24 & $0.440 *$ & $0.626 * *$ & 0.0863 & $0.530 * *$ \\
\hline Age25-34 & $0.280^{*}$ & 0.165 & 0.158 & 0.0627 \\
\hline Age45-54 & -0.162 & 0.0694 & 0.0827 & 0.0537 \\
\hline Age55-64 & -0.163 & $0.305^{*}$ & 0.0624 & $0.374 *$ \\
\hline Age65- & $-0.566 * *$ & 0.116 & -0.0189 & 0.184 \\
\hline Edu1 & 0.178 & 0.209 & 0.163 & 0.145 \\
\hline Edu2 & $0.471^{(*)}$ & $0.485^{*}$ & $0.0650^{(*)}$ & $0.525 * *$ \\
\hline Edu3 & $0.574 *$ & $1.060 * * *$ & $0.580^{(*)}$ & $1.051 * * *$ \\
\hline Edu4 & $0.815^{* *}$ & $1.351 * * *$ & $0.760 *$ & $1.084 * * *$ \\
\hline Edu5 & $0.795 * *$ & $1.121 * * *$ & 0.436 & $1.068 * * *$ \\
\hline Married & 0.187 & 0.104 & -0.00889 & 0.0339 \\
\hline Divorced & $0.424^{(*)}$ & -0.0693 & 0.121 & -0.197 \\
\hline Single & 0.200 & $0.350^{(*)}$ & 0.0630 & 0.206 \\
\hline \multirow[t]{4}{*}{ StdInc } & 0.0420 & $0.0727^{(*)}$ & -0.0130 & 0.0531 \\
\hline & Area dummies & & Area dummies & \\
\hline & \multicolumn{2}{|l|}{ rho $=0.336 * * *$} & \multicolumn{2}{|l|}{ rho $=0.269^{* * *}$} \\
\hline & & & & \\
\hline
\end{tabular}

\begin{tabular}{|c|c|c|c|c|}
\hline Latvia, $n=1069$ & SpPas111 & SpAct111 & SpPas110 & SpAct110 \\
\hline \multicolumn{5}{|l|}{ BMI } \\
\hline Female & $-0.552 * * *$ & $-0.182 *$ & $-0.384 * * *$ & -0.142 \\
\hline Age15-24 & $0.472 * *$ & $0.592 * *$ & $0.451^{*}$ & $0.467 *$ \\
\hline Age25-34 & 0.212 & 0.202 & 0.0273 & 0.0944 \\
\hline Age45-54 & $-0.421 * *$ & $-0.317 *$ & -0.170 & $-0.297 *$ \\
\hline Age55-64 & $-0.692 * * *$ & $-0.714 * * *$ & $-0.782 * * *$ & $-0.643 * * *$ \\
\hline Age65- & $-1.033 * * *$ & $-0.540 * * *$ & $-0.647 * *$ & $-0.337 *$ \\
\hline Edu1 & 0.286 & 0.167 & -0.352 & 0.115 \\
\hline Edu2 & 0.200 & 0.304 & 0.201 & 0.203 \\
\hline Edu3 & 0.716 & 0.774 & 0.253 & 0.648 \\
\hline Edu4 & 0.551 & 0.645 & 0.301 & 0.510 \\
\hline Edu5 & 0.735 & 0.579 & 0.359 & 0.430 \\
\hline Married & $0.462 * *$ & 0.232 & 0.373 & 0.208 \\
\hline Divorced & $0.406^{*}$ & 0.132 & 0.00710 & 0.106 \\
\hline Single & $0.412^{(*)}$ & 0.0585 & 0.373 & 0.213 \\
\hline \multirow[t]{4}{*}{ StdInc } & -0.0122 & -0.00622 & -0.0141 & $-0.0191 *$ \\
\hline & Area dummies & & Area dummies & \\
\hline & \multicolumn{2}{|l|}{$\mathrm{rho}=0.661 * * *$} & \multicolumn{2}{|l|}{ rho $=0.594 * * *$} \\
\hline & & & & \\
\hline
\end{tabular}




\begin{tabular}{|c|c|c|c|c|}
\hline Mexico, $n=1588$ & SpPas111 & SpAct111 & SpPas110 & SpAct110 \\
\hline BMI & -0.00537 & $-0.00927^{(*)}$ & 0.00533 & 0.00573 \\
\hline Female & $-0.361 * * *$ & $-0.146^{*}$ & $-0.293 * * *$ & $-0.127^{(*)}$ \\
\hline Age15-24 & -0.102 & -0.193 & -0.185 & -0.0703 \\
\hline Age25-34 & $-0.231 *$ & -0.0460 & $-0.192^{(*)}$ & -0.0307 \\
\hline Age45-54 & $-0.219 *$ & -0.119 & $-0.280 *$ & -0.0171 \\
\hline Age55-64 & $-0.406 * *$ & -0.194 & $-0.470 * *$ & -0.159 \\
\hline Age65- & $-0.943 * * *$ & $-0.565 * * *$ & $-0.878 * * *$ & $-0.411 * *$ \\
\hline Edu1 & 0.137 & 0.0587 & $0.243^{(*)}$ & $0.270^{*}$ \\
\hline Edu2 & $0.284^{*}$ & $0.268^{*}$ & $0.327 *$ & $0.299 * *$ \\
\hline Edu3 & $0.691 * * *$ & $0.679 * * *$ & $0.481 * * *$ & $0.550 * * *$ \\
\hline Edu4 & $0.325 *$ & $0.587 * * *$ & $0.503 * *$ & $0.551^{* *}$ \\
\hline Edu5 & $0.775 * * *$ & $0.766^{* * * *}$ & $0.575 * * *$ & $0.732 * * *$ \\
\hline Married & 0.139 & -0.0307 & 0.0114 & -0.0963 \\
\hline Divorced & -0.247 & -0.166 & $-0.463^{*}$ & $-0.315^{*}$ \\
\hline Single & 0.192 & $0.321 *$ & 0.159 & $0.307 *$ \\
\hline \multirow[t]{4}{*}{ StdInc } & 0.00163 & -0.00120 & 0.00514 & 0.00430 \\
\hline & Area dummies & & Area dummies & \\
\hline & \multicolumn{2}{|l|}{ rho $=0.500 * * *$} & \multicolumn{2}{|l|}{ rho $=0.414 * * *$} \\
\hline & & & & \\
\hline
\end{tabular}

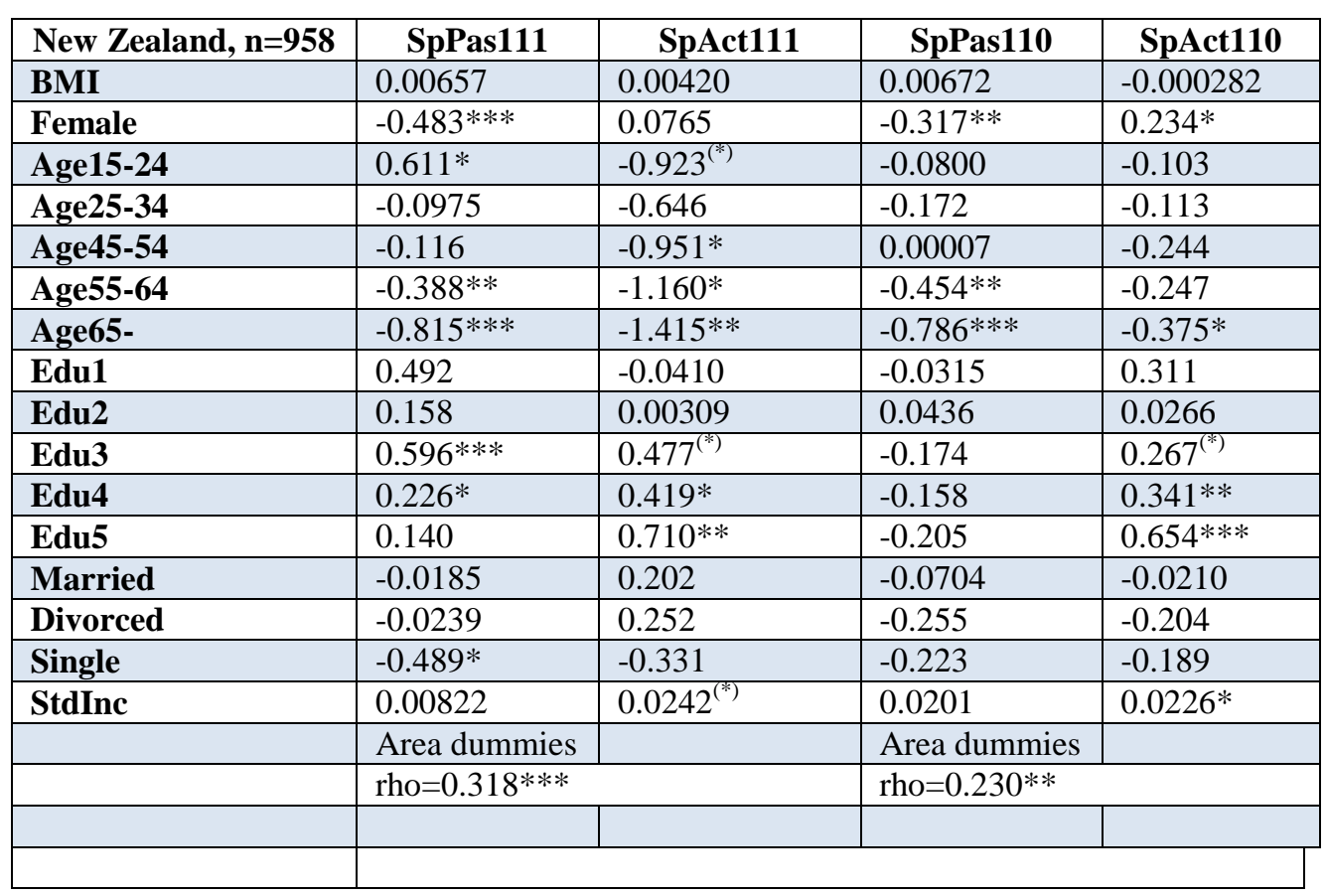




\begin{tabular}{|c|c|c|c|c|}
\hline Norway, n=1127 & SpPas111 & SpAct111 & SpPas110 & SpAct110 \\
\hline \multicolumn{5}{|l|}{ BMI } \\
\hline Female & $-0.458 * * *$ & $0.322 *$ & $-0.375 * * *$ & $0.342 * * *$ \\
\hline Age15-24 & -0.202 & 0.589 & -0.232 & $0.514^{*}$ \\
\hline Age25-34 & $-0.228^{(*)}$ & -0.249 & -0.236 & 0.134 \\
\hline Age45-54 & $-0.239 *$ & -0.0380 & -0.204 & -0.00393 \\
\hline Age55-64 & $-0.543 * * *$ & $-0.434^{(*)}$ & $-0.638 * * *$ & -0.147 \\
\hline Age65- & $-0.795 * * *$ & $-0.512^{*}$ & $-0.903 * * *$ & -0.189 \\
\hline Edu1 & 0.749 & -0.698 & 4.746 & -0.928 \\
\hline Edu2 & 0.776 & -0.278 & 4.673 & -0.806 \\
\hline Edu3 & 0.794 & -0.123 & 4.748 & -0.583 \\
\hline Edu4 & $0.956^{(*)}$ & -0.177 & 4.975 & -0.375 \\
\hline Edu5 & 0.741 & 0.184 & 4.642 & -0.106 \\
\hline Married & 0.194 & 0.0655 & 0.156 & -0.0604 \\
\hline Divorced & 0.0842 & -0.347 & 0.193 & -0.254 \\
\hline Single & 0.137 & 0.185 & 0.165 & -0.155 \\
\hline \multirow[t]{4}{*}{ StdInc } & 0.0115 & $0.0671 * * *$ & -0.0251 & $0.0362 * *$ \\
\hline & Area dummies & & Area dummies & \\
\hline & \multicolumn{2}{|l|}{ rho $=0.409 * * *$} & \multicolumn{2}{|l|}{ rho $=0.194 *$} \\
\hline & & & & \\
\hline
\end{tabular}

\begin{tabular}{|c|c|c|c|c|}
\hline Philippines, n=1197 & SpPas111 & SpAct111 & SpPas110 & SpAct110 \\
\hline BMI & 0.00288 & 0.00395 & 0.00146 & $0.00830^{(*)}$ \\
\hline Female & $-0.716 * * *$ & $-0.479 * * *$ & $-0.738 * * *$ & $-0.629 * * *$ \\
\hline Age15-24 & 0.0615 & 0.139 & 0.0137 & 0.216 \\
\hline Age25-34 & -0.0612 & 0.0787 & 0.0146 & 0.00668 \\
\hline Age45-54 & -0.193 & $-0.208^{(*)}$ & $-0.435 * * *$ & $-0.325 *$ \\
\hline Age55-64 & -0.0148 & -0.123 & 0.0692 & 0.0403 \\
\hline Age65- & $-0.465 * *$ & $-0.497 * *$ & -0.117 & $-0.364 *$ \\
\hline Edu1 & 0.467 & 0.306 & $0.932^{(*)}$ & 0.55 \\
\hline Edu2 & 0.524 & 0.339 & $1.245^{*}$ & 0.727 \\
\hline Edu3 & $0.826^{*}$ & 0.446 & $1.351 *$ & 0.759 \\
\hline Edu4 & $0.847 *$ & $0.615^{(*)}$ & $1.545 * *$ & $1.043 *$ \\
\hline Edu5 & $0.910 *$ & $0.702^{(*)}$ & $1.544 * *$ & $1.009 *$ \\
\hline Married & 0.0898 & -0.0615 & 0.149 & 0.0788 \\
\hline Divorced & 0.331 & 0.300 & $0.600^{(*)}$ & 0.205 \\
\hline Single & 0.167 & 0.272 & 0.187 & 0.281 \\
\hline \multirow[t]{4}{*}{ StdInc } & -0.00143 & -0.0126 & 0.0134 & 0.00938 \\
\hline & Area dummies & & & \\
\hline & \multicolumn{2}{|l|}{ rho $=0.573 * * *$} & \multicolumn{2}{|l|}{ rho $=0.502 * * *$} \\
\hline & & & & \\
\hline
\end{tabular}




\begin{tabular}{|c|c|c|c|c|}
\hline Poland, $\mathrm{n}=1272$ & SpPas111 & SpAct111 & SpPas110 & SpAct110 \\
\hline BMI & -0.0125 & 0.00571 & -0.00335 & 0.0102 \\
\hline Female & $-0.545 * * *$ & $-0.274 * * *$ & $-0.562 * * *$ & $-0.176^{*}$ \\
\hline Age15-24 & $0.621 * * *$ & $0.889 * * *$ & $0.845 * * *$ & $0.818 * * *$ \\
\hline Age25-34 & 0.0783 & 0.0965 & $-0-0465$ & -0.00190 \\
\hline Age45-54 & -0.160 & $-0.214^{(*)}$ & 0.0508 & $-0-178$ \\
\hline Age55-64 & $-0.413 * * *$ & $-0.475 * * *$ & 0.0298 & $-0.248^{(*)}$ \\
\hline Age65- & $-0.823 * * *$ & $-0.565 * * *$ & -0.250 & $-0.249^{(*)}$ \\
\hline \multicolumn{5}{|l|}{ Edu1 } \\
\hline Edu2 & $0.383^{*} * *$ & $0.209^{(*)}$ & $0.553 * *$ & $0.311 *$ \\
\hline Edu3 & $0.572 * * *$ & $0.697 * * *$ & $0.383 *$ & $0.634 * * *$ \\
\hline Edu4 & $0.460 * *$ & $0.707 * * *$ & 0.0982 & $0.730 * * *$ \\
\hline Edu5 & $0.740 * * *$ & $1.441 * * *$ & $0.758 * * *$ & $1.291 * * *$ \\
\hline Married & -0.0510 & $0.268^{*}$ & -0.0514 & $0.226^{(*)}$ \\
\hline Divorced & 0.0633 & 0.305 & 0.340 & $0.422 *$ \\
\hline Single & -0.0809 & $0.323 *$ & -0.152 & $0.412 *$ \\
\hline \multirow[t]{4}{*}{ StdInc } & 0.0140 & $0.0356^{*}$ & 0.00860 & $0.0310^{(*)}$ \\
\hline & Area dummies & & & \\
\hline & \multicolumn{2}{|l|}{ rho $=0.484 * * *$} & \multicolumn{2}{|l|}{ rho $=0.345 * * *$} \\
\hline & & & & \\
\hline
\end{tabular}

\begin{tabular}{|c|c|c|c|c|}
\hline Russia, $n=1998$ & SpPas111 & SpAct111 & SpPas110 & SpAct110 \\
\hline BMI & $0.00754 *$ & $0.0131 * * *$ & -0.00582 & $0.00894 * *$ \\
\hline Female & $-0.540 * * *$ & $-0.296 * * *$ & $-0.451 * * *$ & $-0.229 * * *$ \\
\hline Age15-24 & $0.390 * *$ & $0.850 * * *$ & 0.192 & $0.708 * * *$ \\
\hline Age25-34 & 0.111 & $0.383 * * *$ & -0.0370 & $0.237 *$ \\
\hline Age45-54 & $-0.299 * *$ & $-0.220 *$ & $-0.328 *$ & $-0.232^{*}$ \\
\hline Age55-64 & $-0.435 * * *$ & $-0.503 * * *$ & $-0.366^{*}$ & $-0.366^{* *}$ \\
\hline Age65- & $-0.898 * * *$ & $-0.663 * * *$ & $-0.925 * * *$ & $-0.438 * * *$ \\
\hline \multicolumn{5}{|l|}{ Edu1 } \\
\hline Edu2 & 0.361 & 0.0179 & 0.0657 & 0.0455 \\
\hline Edu3 & $0.358^{(*)}$ & 0.206 & 0.0817 & 0.196 \\
\hline Edu4 & $0.583 * *$ & $0.473 * *$ & 0.243 & $0.397 * *$ \\
\hline Edu5 & $0.831 * * *$ & $0.861 * * *$ & 0.322 & $0.733 * * *$ \\
\hline Married & 0.0666 & -0.0413 & -0.0758 & -0.0445 \\
\hline Divorced & 0.0559 & -0.00288 & -0.0746 & 0.00246 \\
\hline Single & $0.422 * *$ & 0.132 & 0.142 & 0.156 \\
\hline \multirow[t]{4}{*}{ StdInc } & 0.00488 & -0.00857 & 0.0349 & -0.00318 \\
\hline & Area dummies & & & \\
\hline & \multicolumn{2}{|l|}{ rho $=0.591 * * *$} & \multicolumn{2}{|l|}{ rho $=0.512 * * *$} \\
\hline & & & & \\
\hline
\end{tabular}




\begin{tabular}{|l|l|l|l|l|}
\hline Slovakia, n=1123 & \multicolumn{1}{|c|}{ SpPas111 } & \multicolumn{1}{|c|}{ SpAct111 } & \multicolumn{1}{|c|}{ SpPas110 } & \multicolumn{1}{|c|}{ SpAct110 } \\
\hline BMI & -0.00111 & -0.00287 & 0.0111 & 0.000792 \\
\hline Female & $-0.981^{* * *}$ & -0.0167 & $-0.865^{* * *}$ & 0.0462 \\
\hline Age15-24 & $0.538^{* *}$ & $0.693^{* *}$ & $0.341^{* *}$ & $0.444^{*}$ \\
\hline Age25-34 & -0.0357 & $0.289^{* *}$ & 0.0272 & 0.211 \\
\hline Age45-54 & $-0.266^{*}$ & -0.229 & -0.0389 & $-0.390^{* *}$ \\
\hline Age55-64 & $-0.564^{* * *}$ & -0.131 & $-0.314^{*}$ & -0.179 \\
\hline Age65- & $-0.636^{* *}$ & -0.200 & $-0.312^{* *}$ & $-0.277^{* *}$ \\
\hline Edu1 & 0.535 & -0258 & & \\
\hline Edu2 & 0.679 & 0.0340 & 0.0364 & 0.216 \\
\hline Edu3 & 0.792 & 0.508 & 0.116 & $0.618^{* * *}$ \\
\hline Edu4 & 0.677 & 0.577 & 0.0228 & $0.677^{*}$ \\
\hline Edu5 & 0.682 & 0.770 & -0.0456 & $0.955^{* * *}$ \\
\hline Married & -0.0839 & $0.325^{*}$ & 0.0416 & 0.0976 \\
\hline Divorced & -0.0641 & $0.310^{(*)}$ & -0.0809 & 0.0845 \\
\hline Single & 0.0318 & $0.325^{(*)}$ & 0.275 & 0.222 \\
\hline StdInc & 0.0154 & 0.0168 & 0.0137 & -0.00738 \\
\hline & Area dummies & \multicolumn{5}{|l}{} \\
\hline & rho=0.426*** & rho $=0.388^{* * *}$ & \\
\hline & \multicolumn{5}{|l|}{} \\
\hline & \multicolumn{5}{|l|}{} \\
\hline
\end{tabular}

\begin{tabular}{|l|l|l|l|l|}
\hline Slovenia, n= 1000 & \multicolumn{1}{|c|}{ SpPas111 } & \multicolumn{1}{|c|}{ SpAct111 } & \multicolumn{1}{|c|}{ SpPas110 } & SpAct110 \\
\hline BMI & & & & \\
\hline Female & $-0.704^{* * *}$ & -0.0286 & $-0.433^{* * *}$ & 0.0482 \\
\hline Age15-24 & 0.233 & $1.312^{* * *}$ & -0.0414 & $0.789^{* * *}$ \\
\hline Age25-34 & 0.203 & $0.688^{* *}$ & -0.00367 & $0.367^{*}$ \\
\hline Age45-54 & -0.0199 & -0.0377 & 0.0830 & -0.00575 \\
\hline Age55-64 & -0.230 & -0.163 & 0.0868 & 0.0987 \\
\hline Age65- & $-0.782^{* * *}$ & $-0.372^{*}$ & $-0.490^{*}$ & -0.0801 \\
\hline Edu1 & 0.197 & 0.171 & -0.0511 & $0.352^{* *}$ \\
\hline Edu2 & 0.149 & $0.587^{* *}$ & 0.159 & $0.618^{* *}$ \\
\hline Edu3 & $0.540^{(*)}$ & $0.982^{* * *}$ & 0.273 & $1.082^{* * *}$ \\
\hline Edu4 & $0.434^{(*)}$ & $1.318^{* * *}$ & 0.0113 & $1.426^{* * *}$ \\
\hline Edu5 & 0.104 & $1.646^{* * *}$ & -0.125 & $1.323^{* * *}$ \\
\hline Married & 0.262 & 0.0514 & -0.0913 & -0.0811 \\
\hline Divorced & 0.0533 & 0.0719 & -0.245 & 0.155 \\
\hline Single & $0.335^{(*)}$ & 0.0429 & 0.132 & 0.192 \\
\hline StdInc & 0.00166 & 0.0218 & 0.0135 & 0.0133 \\
\hline & Area dummies & \multicolumn{3}{|l}{} \\
\hline & rho=0.562*** & rho=0.348*** & \\
\hline & \multicolumn{5}{|l|}{} \\
\hline & \multicolumn{5}{|l|}{} \\
\hline
\end{tabular}




\begin{tabular}{|c|c|c|c|c|}
\hline South Africa, $\mathbf{n}=2897$ & SpPas111 & SpAct111 & SpPas110 & SpAct110 \\
\hline \multicolumn{5}{|l|}{ BMI } \\
\hline Female & $-0.659 * * *$ & $-0.489 * * *$ & $-0.680 * * *$ & $-0.512 * * *$ \\
\hline Age15-24 & $0.457 * * *$ & $0.682 * * *$ & $0.410 * * *$ & $0.684 * * *$ \\
\hline Age25-34 & $0.209 * *$ & $0.184 *$ & 0.131 & $0.158^{(*)}$ \\
\hline Age45-54 & $-0.194 *$ & -0.0854 & $-0.281 * *$ & -0.0996 \\
\hline Age55-64 & $-0.200^{(*)}$ & $-0.397 * * *$ & $-0.263^{*}$ & $-0.338 * *$ \\
\hline Age65- & $-0.737 * * *$ & $-0.526 * * *$ & $-0.850 * * *$ & $-0.439 * * *$ \\
\hline Edu1 & -0.292 & $-0.711 *$ & 0.266 & -0.445 \\
\hline Edu2 & 0.0333 & -0.449 & $0.570^{(*)}$ & -0.0189 \\
\hline Edu3 & 0.0573 & -0.234 & 0.406 & -0.0550 \\
\hline Edu4 & 0.502 & 0.170 & $0.724 *$ & 0.456 \\
\hline Edu5 & $0.550^{(*)}$ & 0.256 & $0.692 *$ & $0.495^{(*)}$ \\
\hline Married & $0.476^{* * *}$ & 0.161 & $0.372 * *$ & 0.137 \\
\hline Divorced & $0.377^{*}$ & 0.127 & 0.277 & 0.129 \\
\hline Single & $0.400 * *$ & 0.0317 & $0.408 * *$ & 0.0481 \\
\hline \multirow[t]{4}{*}{ StdInc } & $0.0155^{(*)}$ & 0.0107 & 0.00402 & 0.0114 \\
\hline & Area dummies & & & \\
\hline & \multicolumn{2}{|l|}{$\mathrm{rho}=0.563 * * *$} & \multicolumn{2}{|c|}{ rho $=0.550 * * *$} \\
\hline & & & & \\
\hline
\end{tabular}

\begin{tabular}{|c|c|c|c|c|}
\hline Sweden, $n=1292$ & SpPas111 & SpAct111 & SpPas110 & SpAct110 \\
\hline \multicolumn{5}{|l|}{ BMI } \\
\hline Female & $-0.546 * * *$ & $0.238^{(*)}$ & $-0.386 * * *$ & $0.401 * * *$ \\
\hline Age15-24 & -0.198 & 0.365 & -0.00860 & $0.360^{(*)}$ \\
\hline Age25-34 & 0.00889 & -0.0416 & $-0.386^{*}$ & 0.206 \\
\hline Age45-54 & -0.192 & 0.218 & -0.200 & $0.303^{*}$ \\
\hline Age55-64 & $-0.454 * * *$ & 0.100 & $-0.480 * *$ & $0.221^{(*)}$ \\
\hline Age65- & $-0.555 * * *$ & -0.146 & $-0.515^{* *}$ & $0.247^{(*)}$ \\
\hline Edu1 & $0.744 * *$ & 0.444 & 0.783 & 0.185 \\
\hline Edu2 & $0.655^{*}$ & $0.765^{*}$ & 0.912 & 0.372 \\
\hline Edu3 & $0.858 * *$ & $1.200 * *$ & 0.950 & $0.504^{(*)}$ \\
\hline Edu4 & $0.886 * *$ & $1.305 * *$ & 0.521 & $0.858 * *$ \\
\hline Edu5 & $0.646^{*}$ & $1.257 * * *$ & 0.701 & $0.716^{*}$ \\
\hline Married & -0.0125 & -0.335 & 0.00376 & -0.184 \\
\hline Divorced & $-0.454^{(*)}$ & -0.489 & 0.115 & -0.415 \\
\hline Single & -0.0695 & -0.394 & 0.0676 & -0.194 \\
\hline \multirow[t]{3}{*}{ StdInc } & 0.0177 & 0.0158 & 0.00937 & 0.0133 \\
\hline & Area dummies & & & \\
\hline & \multicolumn{2}{|l|}{ rho $=0.274 * *$} & \multicolumn{2}{|l|}{ rho $=0.227 * *$} \\
\hline & & & & \\
\hline
\end{tabular}




\begin{tabular}{|c|c|c|c|c|}
\hline Switzerland, n=998 & SpPas111 & SpAct111 & SpPas110 & SpAct110 \\
\hline BMI & 0.000701 & 0.00283 & $0.0206^{(*)}$ & -0.0120 \\
\hline Female & $-0.551 * * *$ & 0.149 & $-0.459 * * *$ & $0.241^{*}$ \\
\hline Age15-24 & 0.0569 & 0.528 & 0.271 & 0.184 \\
\hline Age25-34 & -0.00397 & 0.0372 & -0.0271 & -0.0584 \\
\hline Age45-54 & $-0.298^{*}$ & -0245 & -0.151 & -0.132 \\
\hline Age55-64 & $-0.427 * *$ & 0.148 & $-0.304^{(*)}$ & $0.339^{(*)}$ \\
\hline Age65- & $-0.993 * * *$ & $-0.467 *$ & $-0.534 * *$ & -0.136 \\
\hline Edu1 & -0.148 & 0.486 & -0.185 & 0.750 \\
\hline Edu2 & 0.218 & $1.352^{*}$ & 0.0123 & $1.542 * *$ \\
\hline Edu3 & 0.153 & $1.694 * *$ & -0.236 & $1.592 * *$ \\
\hline Edu4 & 0.0654 & $1.653 * *$ & -0.256 & $1.876 * * *$ \\
\hline Edu5 & -0.0480 & $1.672 * *$ & -0.341 & $1.920 * * *$ \\
\hline Married & -0.0833 & -0.227 & 0.212 & 0.0109 \\
\hline Divorced & -0.106 & -0.316 & 0.289 & -0.0243 \\
\hline Single & -0.134 & -0.00661 & 0.0490 & 0.153 \\
\hline \multirow[t]{4}{*}{ StdInc } & 0.0152 & 0.0335 & -0.0238 & 0.0150 \\
\hline & $\begin{array}{l}\text { Area } \\
\text { dummies }\end{array}$ & & & \\
\hline & \multicolumn{2}{|l|}{ rho $=0.365^{* * *}$} & \multicolumn{2}{|l|}{ rho $=0.346^{* * *}$} \\
\hline & & & & \\
\hline
\end{tabular}

\begin{tabular}{|c|c|c|c|c|}
\hline Great Britain, n=865 & SpPas111 & SpAct111 & SpPas110 & SpAct110 \\
\hline \multicolumn{5}{|l|}{ BMI } \\
\hline Female & $-0.466 * * *$ & 0.115 & $-0.526 * * *$ & 0.111 \\
\hline Age15_24 & 0.00995 & 0.608 & 0.161 & $0.451^{(*)}$ \\
\hline Age25_34 & -0.153 & -0.0187 & -0.0167 & 0.0851 \\
\hline Age45 54 & $-0.375^{* *}$ & -0.0435 & -0.239 & 0.0338 \\
\hline Age55_64 & -0.226 & 0.256 & 0.0163 & 0.241 \\
\hline Age65 & $-0.532 * * *$ & -0.277 & $-0.533 *$ & -0.182 \\
\hline Edu1 & $0.383 *$ & $0.576^{*}$ & $0.541 *$ & $0.400 *$ \\
\hline Edu2 & $0.475 * *$ & $0.511 * *$ & $0.387^{(*)}$ & $0.516 * * *$ \\
\hline Edu3 & $0.420 * *$ & $0.681 * *$ & 0.272 & $0.589 * * *$ \\
\hline Edu4 & $0.549 * * *$ & $1.099 * * *$ & 0.130 & $0.861 * * *$ \\
\hline Edu5 & $0.527 * * *$ & $0.937 * * *$ & 0.0943 & $0.787 * * *$ \\
\hline Married & -0.00832 & -0.0233 & $-0.260^{(*)}$ & $-0.234^{(*)}$ \\
\hline Divorced & 0.191 & -0.131 & -0.213 & -0.0429 \\
\hline Single & -0.115 & -0.0107 & -0.222 & -0.205 \\
\hline \multirow[t]{4}{*}{ StdInc } & 0.0182 & $0.0410 *$ & 0.0338 & 0.0171 \\
\hline & $\begin{array}{l}\text { Area } \\
\text { dummies }\end{array}$ & & & \\
\hline & rho $=0.623 * * *$ & & rho $=0.214^{*}$ & \\
\hline & & & & \\
\hline
\end{tabular}




\begin{tabular}{|c|c|c|c|c|}
\hline USA, $n=1533$ & SpPas111 & SpAct111 & SpPas110 & SpAct110 \\
\hline \multicolumn{5}{|l|}{ BMI } \\
\hline Female & $-0.172 *$ & 0.0291 & $0.162^{(*)}$ & 0.0147 \\
\hline Age15-24 & -0.118 & -0.00311 & 0.175 & $0.427 *$ \\
\hline Age25-34 & -0.0742 & 0.0394 & -0.0717 & $0.241 *$ \\
\hline Age45-54 & -0.0399 & $-0.379 *$ & $-0.247 *$ & -0.0223 \\
\hline Age55-64 & $-0.355 * *$ & $-0.541 * * *$ & $-0.473 * * *$ & -0.0432 \\
\hline Age65- & $-0.665 * * *$ & $-0.731 * * *$ & $-0.593 * * *$ & $-0.258 *$ \\
\hline Edu1 & 0.273 & 0.561 & -0.0904 & 0.407 \\
\hline Edu2 & 0.397 & 0.497 & 0.313 & 0.460 \\
\hline Edu3 & $0.800 *$ & $0.885 * *$ & 0.385 & $0.670 *$ \\
\hline Edu4 & $1.115 * *$ & $1.387 * * *$ & 0.560 & $1.100 * * *$ \\
\hline Edu5 & $1.260 * * *$ & $1.694 * * *$ & 0.541 & $1.298 * * *$ \\
\hline Married & 0.114 & $0.294 *$ & -0.103 & 0.190 \\
\hline Divorced & -0.186 & 0.159 & $-0.409 *$ & 0.123 \\
\hline Single & -0.177 & 0.0440 & $-0.401 *$ & -0.0156 \\
\hline \multirow[t]{4}{*}{ StdInc } & 0.0196 & $0.0301^{(*)}$ & -0.00668 & 0.0219 \\
\hline & $\begin{array}{l}\text { Area } \\
\text { dummies }\end{array}$ & & & \\
\hline & \multicolumn{2}{|l|}{ rho $=0.468 * * *$} & \multicolumn{2}{|l|}{ rho $=0.233 * * *$} \\
\hline & & & & \\
\hline
\end{tabular}

\begin{tabular}{|c|c|c|c|c|}
\hline Uruguay, $n=1432$ & SpPas111 & SpAct111 & SpPas110 & SpAct110 \\
\hline BMI & 0.00222 & 0.00457 & 0.00666 & 0.00332 \\
\hline Female & $-0.662 * * *$ & $-0.390 * * *$ & $-0.531 * * *$ & $-0.352 * * *$ \\
\hline Age15-24 & 0.0671 & $0.432 * *$ & 0.0505 & $0.488 * * *$ \\
\hline Age25-34 & -0.0366 & 0.126 & 0.0263 & 0.175 \\
\hline Age45-54 & -0.115 & $0.188^{(*)}$ & -0.0281 & $0.236^{*}$ \\
\hline Age55-64 & $-0.303^{*}$ & -0.00273 & -0.239 & 0.138 \\
\hline Age650 & $-0.459 * * *$ & $0.223^{(*)}$ & $-0.305 *$ & $0.231^{(*)}$ \\
\hline \multicolumn{5}{|l|}{ Edu1 } \\
\hline Edu2 & $0.385 * * *$ & $0.329 * * *$ & $0.244^{*}$ & $0.280 * *$ \\
\hline Edu3 & $0.416^{* * *}$ & $0.478 * * *$ & 0.147 & $0.371 * * *$ \\
\hline Edu4 & $1.062 * * *$ & $1.078 * * *$ & $0.348^{*}$ & $0.825 * * *$ \\
\hline Edu5 & $0.379 * *$ & $0.964 * * *$ & -0.105 & $0.729 * * *$ \\
\hline Married & -0.0923 & -0.103 & -0.105 & -0.183 \\
\hline Divorced & -0.156 & -0.0734 & -0.175 & -0.114 \\
\hline Single & -0.0288 & -0.153 & 0.168 & -0.0175 \\
\hline \multirow[t]{4}{*}{ StdInc } & $0.0457 * *$ & 0.0108 & $0.0756 * *$ & 0.00867 \\
\hline & Area dummies & & & \\
\hline & \multicolumn{2}{|l|}{ rho $=0.309 * * *$} & \multicolumn{2}{|l|}{ rho $=0.387 * * *$} \\
\hline & & & & \\
\hline
\end{tabular}




\section{References}

Borland J, MacDonald R (2003) Demand for sport. Oxford Review of Economic Policy 19: 478-502.

Breuer C, Hallmann K, Wicker P (2010) Socio-economic patterns of sport demand and ageing. European Review of Aging and Physical Activity 7(2): 61-70.

Cabane C, Lechner M (2014) Physical activity of adults: a survey of correlates, determinants, and effects. ZEW Discussion Papers No. 14-088.

De Bosscher V, De Knop P, Van Bottenburg M, Shibli S (2006) A conceptual framework for analysing sports policy factors leading to international sporting success. European Sport Management Quarterly 6: 185-215.

Downward P (2007) Exploring the economic choice to participate in sport: results from the 2002 general household survey. International Review of Applied Economics 21: 633-653.

Downward P, Riordan J (2007) Social interactions and the demand for sport: an economic analysis. Contemporary Economic Policy 25(4): 518-537.

Eberth B, Smith MD (2010) Modelling the participation decision and duration of sporting activity in Scotland. Economic Modelling 27: 822-834.

Funk DC, Toohey K, Bruun T (2007) International Sport Event Participation: Prior Sport Involvement; Destination Image; and Travel Motives. European Sport Management Quarterly 3: 227-248.

García J, Lera-López F, Suárez MJ (2011) Estimation of a structural model of the determinants of the time spent on physical activity and sport: evidence for Spain. Journal of Sports Economics 12(5): 515-537.

Hartmann-Tews I (2006) Social stratification in sport and sport policy in the European Union. European Journal for Sport and Society 3: 109-124

Hofstede G (1980) Culture's consequences: Comparing Values, Behaviours, Institutions and Organizations. Sage Publications Inc.

Hofstede G (2002) Dimensions do not exist: a reply to Brendan McSweeny. Human Relations 55: 1-7.

Hofstede, G. (2011). Dimensionalizing cultures: the hofstede model in context. Online Readings in Psychology and Culture 2(1). http://dx.doi.org/10.9707/23070919.1014

Hofstede G, Hofstede G J (2005) Cultures and Organizations: Software of the Mind. New York: McGraw-Hill

Hofstede G, Hofstede GJ, Minkov M (2010) Cultures and Organizations, Software of the Mind, Intercultural Cooperation and Its Importance for Survival ( $3^{\text {rd }}$ eds.). New York: Mc-GrawHill.

Hofstede GJ, Murff E JT (2012) Repurposing an Old Game for an International World. Simulation Gaming 43(1): 34-50.

Humphreys B, Ruseski J (2009) The economics of participation and time spent in physical activity. Working Paper 2009-09, University of Alberta, Department of Economics.

Javidan M, House RJ, Dorfman PW, Hanges PJ, de Luque MS (2006) Conceptualizing and measuring cultures and their consequences: a comparative review of GLOBE's and Hofstede's approaches. Journal of International Business Studies 37: 897-914.

Jokl E (1964) Medical Sociology and Cultural Anthropology of Sport and Physical Education: Thomas.

Maczulskij T, Pehkonen J (2011): Public-private sector pay gaps in Finland: a quantile regression analysis. Finnish Economic Papers 24: 111-127. 
Martinez-Gonzalez MA, Varo JJ, Santos JL, de Irala J, Gibney M, Kearney J and Martinez JA (2001) Prevalence of physical activity during time in European Union. Medicine and Science in Sports and Exercise 33(7): 1142-1146.

Pope S (2013) "The love of my life" the meaning and importance of sport for female fans. Journal of Sport and Social Issues 37: 176-195.

Rovio E, Hakonen H, Laine K, Helakorpi S, Uutela A, Havas E and Tammelin T (2011) Perherakenteen yhteys suomalaisten aikuisten liikunta-aktiivisuuteen [Family link structure of Finnish adults' physical activity]. Liikunta \& Tiede [Sports \& Science] 48: 36-41.

Ruseski J, Maresova K (2014) Economic freedom, sport policy, and individual participation in physical activity: an international comparison. Contemporary Economic Policy 32(1): 42-55.

Soares AM, Farhangmehr M, Shoham A (2007) Hofstede's dimension of culture in international marketing studies. Journal of Business Research 60: 277-284.

Van Tuyckom C (2013) Six sporting worlds. A cluster analysis of sports participation in the EU-25. Quality \& Quantity 47(1): 441-453

Ukkinstituutti (2015) Physical activity pie. Retrieved from http://goo.gl/vU7rdq. [Accessed 11 March 2015]

Wicker P, Hallmann K, Breuer C (2013) Analyzing the impact of sport infrastructure on sport participation using geo-coded data: evidence from multi-level models. Sport Management Review 16: 54-67. 